Portland State University

PDXScholar

\title{
Accommodation Space in a High-Wave-Energy Inner- Shelf During the Holocene Marine Transgression: Correlation of Onshore and Offshore Inner-Shelf Deposits (0-12 ka) in the Columbia River Littoral Cell System, Washington and Oregon, USA
}

\author{
Curt D. Peterson \\ Portland State University, curt.d.peterson@gmail.com \\ Dave C. Twichell \\ Michael C. Roberts \\ Simon Fraser University \\ Sandy Vanderburgh \\ Medicine Hat College \\ Follow this and additional works at: https://pdxscholar.library.pdx.edu/geology_fac \\ Stove W. Hostetler

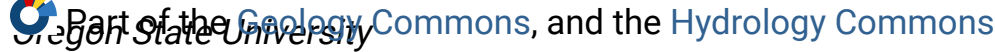 \\ Let us know how access to this document benefits you.
}

\section{Citation Details}

Peterson, C. D., Twichell, D. C., Roberts, M. C., Vanderburgh, S., \& Hostetler, S. W. (2016). Accommodation space in a high-wave-energy inner-shelf during the Holocene marine transgression: Correlation of onshore and offshore inner-shelf deposits (0-12ka) in the Columbia River littoral cell system, Washington and Oregon, USA. Marine Geology.

This Post-Print is brought to you for free and open access. It has been accepted for inclusion in Geology Faculty Publications and Presentations by an authorized administrator of PDXScholar. Please contact us if we can make this document more accessible: pdxscholar@pdx.edu. 


\section{Accepted Manuscript}

Accommodation space in a high-wave-energy inner-shelf during the Holocene marine transgression: Correlation of onshore and offshore inner-shelf deposits $(0-12 \mathrm{ka})$ in the Columbia River littoral cell system, Washington and Oregon, USA

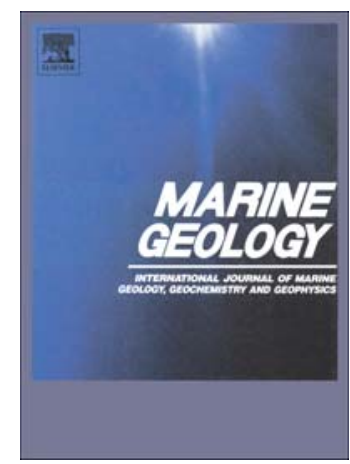

C.D. Peterson, D.C. Twichell, M.C. Roberts, S. Vanderburgh, S.W. Hostetler

PII:

S0025-3227(16)30079-2

DOI: doi: 10.1016/j.margeo.2016.05.007

Reference: MARGO 5461

To appear in: $\quad$ Marine Geology

Received date: 12 December 2015

Revised date: $\quad 9$ May 2016

Accepted date: $\quad 10$ May 2016

Please cite this article as: Peterson, C.D., Twichell, D.C., Roberts, M.C., Vanderburgh, S., Hostetler, S.W., Accommodation space in a high-wave-energy inner-shelf during the Holocene marine transgression: Correlation of onshore and offshore inner-shelf deposits (0-12 ka) in the Columbia River littoral cell system, Washington and Oregon, USA, Marine Geology (2016), doi: 10.1016/j.margeo.2016.05.007

This is a PDF file of an unedited manuscript that has been accepted for publication. As a service to our customers we are providing this early version of the manuscript. The manuscript will undergo copyediting, typesetting, and review of the resulting proof before it is published in its final form. Please note that during the production process errors may be discovered which could affect the content, and all legal disclaimers that apply to the journal pertain. 


\section{Revision 5_01_16}

Accommodation Space In A High-Wave-Energy Inner-Shelf During The Holocene Marine Transgression: Correlation Of Onshore and Offshore Inner-shelf Deposits (0-12 ka) In The Columbia River Littoral Cell System, Washington and Oregon, USA

C.D. Peterson, Portland State University, 1721 SW Broadway, Portland, OR 972070751, United States, curt.d.peterson@gmail.com

D.C. Twichell, PO Box 625, West Falmouth, MA 02574, United States, tdtwichell@aol.com

M.C. Roberts, Departments of Geography and Earth Science, Simon Fraser University, 8888 University Drive, Burnaby, B.C., V5A1S6 Canada, mroberts@sfu.ca

S. Vanderburgh, Medicine Hat College, Medicine Hat, Alberta, T1A3Y6, Canada, svanderburgh@mhc.ab.ca

S.W. Hostetler, Oregon State University, Corvallis, Oregon, 97331, United States, steve@coas.oregonstate.edu

\section{ABSTRACT}


The Columbia River Littoral Cell (CRLC), a high-wave-energy littoral system, extends $160 \mathrm{~km}$ alongshore, generally north of the large Columbia River, and 10-15 $\mathrm{km}$ in across-shelf distance from paleo-beach backshores to about $50 \mathrm{~m}$ present water depths. Onshore drill holes (19 in number and 5-35 $\mathrm{m}$ in subsurface depth) and offshore vibracores (33 in number and 1-5 $\mathrm{m}$ in subsurface depth) constrain inner-shelf sand grain sizes (sample means $0.13-0.25 \mathrm{~mm}$ ) and heavy mineral source indicators ( $>90 \%$ Holocene Columbia River sand) of the inner-shelf facies ( $\geq 90 \%$ fine sand). Stratigraphic correlation of the transgressive ravinement surface in onshore drill holes and in offshore seismic reflection profiles provide age constraints ( $0-12 \mathrm{ka})$ on post-ravinement inner-shelf deposits, using paleo-sea level curves and radiocarbon dates. Post-ravinement deposit thickness (1-50 m) and long-term sedimentation rates $\left(0.4-4.4 \mathrm{~m} \mathrm{ka}^{-1}\right)$ are positively correlated to the cross-shelf gradients (0.36-0.63 \%) of the transgressive ravinement surface. The total post-ravinement fill volume of fine littoral sand $\left(2.48 \times 10^{10} \mathrm{~m}^{3}\right)$ in the innershelf represents about $2.07 \times 10^{6} \mathrm{~m}^{3} \mathrm{yr}^{-1}$ fine sand accumulation rate during the last $12 \mathrm{ka}$, or about one third of the estimated middle- to late-Holocene Columbia River bedload or sand discharge $\left(5-6 \times 10^{6} \mathrm{~m}^{3} \mathrm{yr}^{-1}\right)$ to the littoral zone. The fine sand accumulation in the inner-shelf represents post-ravinement accommodation space resulting from 1) geometry and depth of the transgressive ravinement surface, 2) post-ravinement sea-level rise, and 3) fine sand dispersal in the inner-shelf by combined high-wave-energy and geostrophic flow/down-welling drift currents during major winter storms. 


\section{INTRODUCTION}

Several factors combined to yield unusual depositional conditions in the Columbia River littoral cell (CRLC) inner-self ( $\sim 160 \mathrm{~km}$ in length and $\sim 10-15 \mathrm{~km}$ in width) during the Holocene (Figure 1) (Gelfenbaum and Kaminsky, 2010; Ruggiero et al., 2016). Historic dam impoundments on the Columbia River tributary system (< 125 in number) have altered sediment supply to the lower Columbia River Valley. Early-historic (pre-impoundment) sediment supply was estimated to be $14 \times 10^{6} \mathrm{~m}^{3}$ $\mathrm{yr}^{-1}$ (Sherwood et al., 1990). High sand supply to the incised Columbia River Valley during middle- to late-Holocene time exceeded available accommodation space (Gates, 1994; Baker et al., 2010). Throughput of fine-size sand from the Columbia River to the littoral zone is estimated to have been $\sim 5-6 \times 10^{6} \mathrm{~m}^{3} \mathrm{yr}^{-1}$ after $8 \mathrm{ka}$ (Peterson et al., 2013). High winter-wave-energy in the northeast Pacific Ocean $\left(\mathrm{H}_{\mathrm{s}}=7-13 \mathrm{~m}\right)$ (Tillotsen and Komar, 1997; Ruggiero et. al., 1997) and extreme storm waves (H> $14 \mathrm{~m}$ ) (Allan and Komar, 2002) precluded development of a delta at the mouth of the Columbia River. However, wide barrier spits and beach plains (0.5-4.1 km in width) occur on either side of the Columbia River mouth (Ballard, 1964; Rankin, 1983; Peterson et al., 2010a). The onset(s) of progradation in the wide barrier-spits and beach plains began in late Holocene time (3-5 ka) well after the slowing of marine transgression at 7-9 ka in middle Holocene time (Peterson et al., 2010a; 2010b). In these regards the CRLC inner-shelf differed from some other high-wave energy shelf settings (Thom, 1984; Short, 1987) where transgressive 
submergence of the shelf led to wave ravinement of pre-Holocene shelf deposits and shoreward transport of the remobilized pre-Holocene deposits to feed barrier and beach development in middle Holocene time.

Fine sand dominates inner-shelf deposits of the CRLC, as established by surface grab samples and box cores (Runge, 1966; Venkatarathnam and McManus, 1973; Nittrourer, 1978; Twichell et al., 2010). Large storm surf and wind-stress currents were predicted to sweep nearshore sand deposits both along the shelf (north) and across the shelf (offshore) in the CRLC system (Sternberg and Larsen; 1976; Sternberg, 1986; Katchel and Smith, 1986). Offshore seismic-reflection surveys in the CRLC shelf identified the transgressive ravinement surface that was buried by 5-50 m of Holocene deposits in southern one half of the CRLC inner-shelf (Twichell and Cross, 2001; Twichell et al., 2010). The question arises whether 1) the Columbia River mouth and adjacent beaches were the sources of sand for the thick Holocene inner-shelf deposits or 2) remobilized pre-Holocene shelf deposits were the sources of sand for the wide barriers and beach plains? This study specifically addresses the relations between the origins of the onshore and offshore deposits in the CRLC system. These interpreted relations challenge previous assumptions about accommodation space in some high-wave-energy inner-shelves during marine transgressions. Specifically, how might post-transgressive inner-shelf accommodation space serve as net sink for littoral deposits that are episodically transported offshore?

In this study we combine onshore and offshore sediment composition and stratigraphic analyses for the first time in our ongoing investigations of Holocene 
deposition in the CRLC system (Figure 1). Sand grain size and heavy mineral source indicators are compared between onshore and offshore deposits. The onshore transgressive ravinement surface, as previously radiocarbon dated in onshore drill holes (Vanderburgh et al., 2010), is stratigraphically correlated to the offshore transgressive ravinement surface, as previously interpreted in across-shelf seismic reflection profiles (Twichell and Cross, 2001; Twichell et al., 2010). Estimated ages of the offshore transgressive ravinement surface are estimated from 1) elevations of the ravinement surface in offshore seismic reflection profiles and 2) established paleo-sea level ages from a local relative sea-level curve (Peterson et al., 2010b). Transgressive ravinement surface ages (0-14 ka) are used with radiocarbon ages of shallow deposits in onshore drill holes (1-8 ka) and offshore vibracores (0.6-9 ka) (Kaminsky, 2006) to bracket sedimentation rates in the inner-shelf during the middle- to late-marine transgression ( 0-12 ka). Modeled paleo-wind and wave stress directions (0-21 ka) are compared to corresponding paleo-shoreline orientations to predict changes in net-alongshore transport in the inner-shelf during different time intervals of the marine transgression.

The results from this integrated study of offshore and onshore inner-shelf deposits help to constrain the factors that controlled available accommodation space and partitioning of fine sand in the CRLC system during the Holocene marine transgression (Figure 1). The study results differ substantially from a standard model of transgressive stripping of unconsolidated sediments and/or wave remobilization and shoreward transport of pre-Holocene shelf sand , as previously found in some other USA west-coast shelves (Chin et al., 1997; Peterson et al., 2007). 
Furthermore, these study results have important implications for high-wave-energy shelves responding to potential impacts of predicted global warming and sea level rise (Vermeer and Rahmstorf, 2009) by future increases in inner-shelf accommodation space. Such increases in inner-shelf accommodation space could serve as sinks for available littoral sand resulting in potential widespread beach erosion and associated shoreline retreat in some sediment-starved littoral systems.

\section{BACKGROUND}

The wide beach plains in the CRLC system (Figure 1) are characterized by regional episodic events of coseismic beach retreat (estimated 100-400 m retreat) and interseismic beach accretion (Meyers et al., 1996; Doyle, 1996; Peterson et al., 2000). Interseismic accretion surpassed the episodic coseismic erosion, leading to net progradation rates of $\sim 0.1-0.5 \mathrm{~km} \mathrm{ka}^{-1}$ during late-Holocene time (Woxell, 1998; Peterson et al., 2010a). The innermost-shelf deposits ( $\sim 2-8$ ka in age) that underlie the prograded beach plains ( $\sim 1-5$ ka in age) do not display any evidence of regional catastrophic erosion or accretion, but rather amalgamated plane beds of homogenous fine sand (5-30 thickness) with storm shell-hash interbeds (Herb, 2000; Vanderburgh et al., 2010; Peterson et al., 2010b). The sequential onset of lateHolocene beach progradation (5 -to- 0 ka) was delayed with increasing distance downdrift (20-100 km) from the Columbia River mouth (Peterson et al., 2010a). The very-wide beach plains and barrier spits (3.0-5.0 km width) adjacent to the Columbia River mouth began to prograde by 4.5-5.0 ka (Rankin, 1983; Meyers et al., 
1996; Woxell, 1998). By comparison, the narrow beaches ( $<500 \mathrm{~m}$ width) in the northernmost CRLC ( $>100 \mathrm{~km}$ from the Columbia River mouth) are less than $0.5 \mathrm{ka}$ in age (Peterson et al., 2010a) and they pinch-out seaward towards an eroded bedrock surface in the inner-shelf (Twichell et al., 2010). Seismic-reflection surveys of the central and southern CRLC shelf areas identified the transgressive ravinement surface that was buried by 1-50 m of interpreted Holocene fill (Twichell et al., 2010).

The relations outlined above suggest that littoral sand was supplied to the prograding beaches from the Columbia River mouth, by along-coast net littoral drift in the nearshore and inner-shelf (Peterson et al., 2010b), but not from the trasnsgressive remobilization of pre-Holocene shelf deposits. A deeply-buried transgressive ravinenment surface ( $>30 \mathrm{~m}$ depth subsurface) is interpreted from some across-shelf seismic reflection surveys in the CRLC system (Twichell and Cross, 2001). Unlike the pre-Holocene deposits in the south-central Oregon shelf (Figure 1) that served as the primary source of sand to adjacent beaches and dune fields during the middle- to late-Holocene transgression (Scheidegger et al., 1971; Peterson et al., 2007), the CRLC shelf served as a major sink of littoral sediment $\left(\sim 79 \mathrm{~km}^{3}\right)$ during the marine isotope stage 1 (MIS1) transgression (Twichell et al., 2010). What, therefore, were the factors that permitted the CRLC inner-shelf to serve as a major sink of littoral sand during the middle- to late-Holocene transgression?

Modern bathymetric profiles reported for the inner-shelf by Buijsman et al. (2003) and Kaminsky (2006) show relatively little variation between the four 
subcells, including NOS1 (North Beaches), NOS04 (Grayland Plains), NOS5 (Long Beach Peninsula) and SL23 (Clatsop Plains) (Figure 2 Part A). Though the appropriate use of 'equilibrium' inner-shelf profiles can be debated (Brunn, 1962; Dean 1991; Pilkey et al., 1993) the apparent similarities in the four profiles suggest a relatively uniform dispersal of recent deposits in much of the CRLC system. The high-wave energy (up to 15 m wave height) (Ruggiero et al., 1997; Allan and Komar, 2002), accounts for modern sand deposits (>75\% fine sand) extending to 40-60 m water depth in most of the CRLC system (Figure 2 Part B). This sand deposit grades texturally seaward to a mid-shelf mud lens that extends north of the Columbia River mouth (Nittrouer, 1978). Seasonally reversing wind and wave directions (from northwest in summer and southwest in winter) are important in influencing nearshore sediment dispersal in the region (Peterson et al., 2009; Ruggiero et al., 2916). However, major winter storms are reported to be the dominant factors in sand transport in the inner-shelf (net northward transport) and across-shelf (net offshore transport) due to combined wave oscillatory currents, geostrophic flow and offshore downwelling (Smith and Hopkins, 1972; Sternberg, and Larsen, 1976; Sternberg, 1986; Kachel and Smith, 1986). Relative to the latest-Holocene 'highstand' conditions, little is known about CRLC shelf sedimentation during the earlyto-middle Holocene time (10 to $5 \mathrm{ka}$ ) when the inner-shelf area was transgressed by rapid sea level rise (Figure 2 Part C). In this article we address the sources, sedimentation rates, and transport mechanisms that deposited sand in the CRLC inner-shelf during the last $\sim 12 \mathrm{ka}$. 


\section{METHODS}

Data from several studies were used to assemble the alongshore and acrossshelf transects of inner-shelf sediment composition used in this research (Supplemental Table 1). These transects are used to constrain the length, width, depth and ages of the Holocene inner-shelf deposits in the CRLC system. Seventeen modern beach sites between the Nehalem and Quillayute Rivers (Figure 1) are characterized by their beach/barrier width, slope, and sand composition (Peterson et al., 1994). Samples from the modern beach faces were analyzed for mean and standard deviation of sand grain size on the basis of mechanical sieving at $0.25 \mathrm{phi}$ intervals. In this study the beach sand samples were further analyzed for their relative abundances of two pyroxene minerals of similar shape and density: hypersthene and augite. The ratios of the pyroxene minerals in heavy mineral sand fractions discriminate between sources of sand to the CRLC system, including the local coastal drainages, which are augite rich, and the Holocene Columbia River sediments, containing both hypersthene and augite (Scheidegger et al., 1971; Scheidegger and Phipps, 1976). The heavy mineral separates ( $\geq 3.0 \mathrm{~g} \mathrm{~cm}^{-3}$ density) were analyzed for pyroxene minerals ( $\sim 300$ grains total) under polarizing microscopy at 250x. Across inner-shelf transects are based on 1) shelf facies under prograded barrier and beach plains, as sampled in onshore drill holes (Herb, 2000; Vanderburgh et al., 2010; Peterson et al., 2010b), 2) selected surf zone vibracore samples, as first published here, 3) selected offshore vibracore core samples (Kaminsky, 2006), and 4) offshore surface grab sample data as reported by 
Scheidegger et al. (1971), Venkatarathnam, and McManus (1973) and Twichell and Cross (2001) (Figure 3).

Data from five of the across-shelf transects (L11, L41, L36, L33, L23) and two drill holes (DHwest1 and DHoyst) are compiled to establish downcore (onshore) and across-shelf trends in inner-shelf sand grain size and sediment provenance (Figure 3). Sediment size fractions in onshore and offshore shelf samples were measured by sieving at the $2.0 \mathrm{~mm}$ and $0.062 \mathrm{~mm}$ screen sizes to discriminate the gravel, sand and silt/clay (mud) size fractions. Sand size fractions were analyzed for mean and standard deviation of sand grain size at 0.25 phi intervals (Peterson et al., 2010b; Kaminsky, 2006). Onshore shelf deposit sequences were previously analyzed for sand source provenance using augite and hypersthene mineral ratios (Peterson et al., 2010b). Across-shelf indicators of sand provenance in the CRLC shelf are based on factor loadings for augite-rich and hypersthene-rich end-member factors, as reported for shelf surface grab samples (Scheidegger et al., 1971; Venkatarathnam, and McManus, 1973). In this study the ratios of the factor loadings for the augite-rich and hypersthene-rich factors in the shelf grab samples, as reported by Scheidegger et al. (1971) and Venkatarathnam, and McManus (1973), are used to represent sediment provenance in the nearest shelf vibracore sites, sampled by Kaminsky (2006).

Twelve transects, spaced at about $10 \mathrm{~km}$ distances along the shelf (north to south), include onshore drill holes, offshore seismic profiles, and offshore vibracores. The 12 transects are utilized for stratigraphic correlation of the transgressive ravinement surface and estimates of sedimentation rates in the CRLC 
inner-shelf (Figure 3). Stratigraphic correlations of the dated onshore transgressive ravinement surface (Vanderburgh et al., 2010) and interpreted offshore ravinement surface (Twichell and Cross, 2001; Twichell et al., 2010) are based on similarity of depth, slope, and continuity of the reported ravinement surface. Details about the identification of the transgressive ravinement surface are presented in Herb (2000), Vanderburgh et al. (2010), and Twichell and Cross (2001). Offshore deposit surface depths and transgressive ravinement surface depths were taken from seismic profile stations $(\mathrm{S})$, spaced at about two kilometer intervals across the inner-shelf (east to west) to at least the $50 \mathrm{~m}$ water depth. Two-way travel times of 750 and 800 $\mathrm{m} / \mathrm{s}$, respectively, were used to estimate the modern water depth and the Holocene deposit subsurface depths above the transgressive ravinement surface in the offshore seismic profiles at the vibracore sites (V) and the seismic profile stations (S) . Assuming a lowest frequency of $500 \mathrm{~Hz}$ and a $1600 \mathrm{~m} \mathrm{~s}^{-1}$ seismic velocity, then a one half wave length $(\sim 1.5 \mathrm{~m})$ depth resolution is estimated for the offshore transgressive ravinement surface. Subsurface depths, relative to sea level, are adjusted to elevation (m) NAVD88 for both the offshore and onshore shelf deposit records. The $0 \mathrm{~m}$ NAVD88 datum is about one meter below mean sea level in the study area. The onshore borehole elevation control using LIDAR was estimated to be $\pm 0.5 \mathrm{~m} \mathrm{NAVD88}$ at the time of the study (Daniels, 2001).

\section{RESULTS}

\subsection{Distribution and composition of beach and inner-shelf deposits}


The widths of late Holocene beach, barrier and beach plain deposits vary greatly from $30 \mathrm{~m}$ to at least $4100 \mathrm{~m}$ in across-shore distance in the study region (Supplemental Table 3; Figure 4). Wide beach deposits ( $>300 \mathrm{~m}$ width) only occur between Point Grenville, WA and Seaside, OR. The largest barriers and beach plains ( $>1500 \mathrm{~m}$ in width) in the study area are asymmetrically distributed on either side of the mouth of the Columbia River in the Long Beach and Clatsop subcells. Mean grain sizes of the modern beach samples are generally in the fine sand size $(<0.25$ $\mathrm{mm})$. Mean grain size values of modern beach samples increase substantially $(0.50-$ $1.73 \mathrm{~mm}$ ) north of Kalaloch, WA. The abrupt increase in grain size coincides with the locations of several large coastal river mouths, including those of the Queets, Hoh, and Quillayute Rivers.

The ratios of pyroxene minerals, hypersthene and augite, in modern beach deposits are used to distinguish between Holocene sand supply from the Columbia River (hypersthene-rich) and the local coastal rivers (hypersthene-poor) (Scheidegger et al., 1971; Scheidegger and Phipps, 1976; Peterson et al., 2010b). High hypersthene:augite ratios (0.65-0.9) occur between Whale Cove, WA and Seaside, OR, establishing dominant sand supply from the Columbia River during late Holocene time (Supplemental Table 2; Figure 4). The correlative relations of 1) wide beaches, beach plains and barrier spits, 2) fine sand grain size, and 3) high hypersthene:augite ratios, establish the alongshore extent of the CRLC system (CRLC study area) in onshore deposits, between Seaside, OR, and Point Grenville, WA. Some Holocene Columbia River sand has been transported north, around Point 
Grenville, WA, reaching at least Kalaloch, WA, located $160 \mathrm{~km}$ north of the Columbia River mouth.

Shelf deposit textural data from onshore drill holes in the barrier and beach plains (Figure 3) are summarized from representative intervals of the shelf facies (6-30.5 m subsurface depth) that underlie the shallow beach facies (Supplemental Table 3). One drill hole DHwest1 is located adjacent to the Grays Harbor tidal inlet, which has gravelly-sand interbeds, such as at $14 \mathrm{~m}$ depth (32 percent gravel and 63 percent sand) (Peterson and Phipps, 1992). One drill hole DHoyhu1 from the opposite (north) side of the Grays Harbor tidal inlet contains minor gravel (1-5 percent gravel) at depths of 6.4 and $10 \mathrm{~m}$. Samples located above the Holocene ravinement surface in drill holes located south of DHwest1 contain only sand and mud.

The relative abundances of sand (84-98 percent sand total range) and the mean grain size of the sand fractions $(0.16-1.14 \mathrm{~mm}$ total range) in onshore shelffacies samples (Supplemental Table 3) slightly decrease in the middle-shelf facies intervals relative to the lower- and upper-shelf facies intervals. The small changes in textural compositions downhole are interpreted to reflect changing water depths between post-ravinement transgression and upper shoreface progradation in the innermost-shelf (Peterson et al., 2010b). The mean size and standard deviation of mean grain size for 20 samples with $\geq 84$ percent sand in the drill hole shelf facies are $0.22 \pm 0.6 \mathrm{~mm}$. Mineral tracer data for the innermost-shelf deposits are summarized for upper, middle and bottom samples from three drill holes DHwest1, DHoyst, and DHsuns, respectively in the Grayland, Long Beach, and Clatsop subcells 
(Figure 3). Hypersthene:augite ratios in samples from the three onshore drill holes range from 0.6 to 0.8 for nine samples, demonstrating a dominant sand source from Holocene Columbia River sand supply. The average and standard deviation of hypersthene:augite ratios for the 9 drill hole samples (6.3-30.5 subsurface depth) are $0.75 \pm 08$. Mineral source analyses in one drill hole DHwest 1 , at the mouth of Grays Harbor, extended well below the ravinement surface to -51.1 m elevation in estuarine deposits. A radiocarbon date on an adjacent drill hole (GH02) located 2.3 $\mathrm{km}$ east of DHwest1, provided a date of 10,600 \pm 460 cal yr BP (Beta\#20282) at a depth of -51.5 m elevation (Peterson and Phipps, 1992). Hypersthene:augite ratios of 0.8-0.9 in DHwest1 occurred between $-34.5 \mathrm{~m}$ and $-51.1 \mathrm{~m}$ elevation in the tidal inlet/flood tide delta deposits of Grays Harbor, demonstrating dominant sand supply from the Columbia River to the Grays Harbor embayment since 10 ka.

Representative offshore vibracore samples from 2-4 m depth subsurface are compared for relative sand and mud abundances and mean grain-sizes (total sample) in five across-shore transects (Supplemental Table 3; Figure 5). Twentyfive of the 27 samples from $\leq 50 \mathrm{~m}$ water depth contain $>90$ percent sand. Two samples from $\geq 60 \mathrm{~m}$ water depth (V901 and V902) encountered the mid-shelf mud lens ( $>25$ percent mud) north of the Columbia River mouth, as mapped by Nittrouer (1978). In this paper we define the modern inner-shelf facies on the basis of $>90$ percent sand, which extends to the 40-50 m modern water depth, or about $10 \mathrm{~km}$ distance seaward of the shoreline in the across-shelf transects. Mean sediment grain size in the offshore vibracore samples generally decreases with increasing water depth from the surf zone $(0.20-0.25 \mathrm{~mm})$ to the $40-50 \mathrm{~m}$ water depth intervals 
(0.13-0.17 $\mathrm{mm})$. The average and standard deviation values of mean grain size for 24 vibracore samples in the inner-shelf ( $\leq 50 \mathrm{~m}$ water depth) are $0.18 \pm 0.04 \mathrm{~mm}$ and for 17 samples from the innermost-shelf $(\leq 25 \mathrm{~m}$ water depth) they are $0.19 \pm 0.03$ $\mathrm{mm}$. Because grain size analyses of the inner-shelf vibracores (Kaminsky, 2006) were based on total samples, i.e. sand and small abundances of mud, the total sample mean grain size slightly underestimates the mean size of the sand fraction in some of the shelf vibracore samples.

Mineral tracer proxies for sand source supply to shelf surface deposits are based on multivariate factor loadings for hypersthene-rich factors and augite-rich factors, as previously reported for heavy mineral assemblages in shelf grab samples (Supplemental Table 3). The hypersthene rich-factors correspond to Holocene sand supply from the Columbia River (Scheidegger et al., 1971; Baker et al., 2010). The augite-rich factors are associated with sand supply from 1) pre-Holocene Columbia River bedload (Baker et al., 2010) and 2) coastal rivers and/or glacial outwash deposits located north of Grays Harbor (Figure 4) (Venkatarathnam and McManus, 1973; Scheidegger and Phipps, 1976). Normalized ratios of the hypersthene and augite factor loadings in the nearest grab samples that are located along the five transects (Figure 5) range from 0.3 to 0.8 . The inner-shelf samples ( $\leq 50 \mathrm{~m}$ water depth) from the three central transects (L41, L36, L33) are dominated by Holocene Columbia River sand supply (factor loading ratios 0.8 ).

\subsection{Stratigraphic correlation between onshore and offshore ravinement surface}


Correlations of the onshore and offshore parts of the transgressive ravinement surface are established from the depth, slope and continuity of the ravinement surface in both onshore drill hole logs and offshore seismic reflection profiles. One representative cross-section L33 from the middle of the study area (Figure 3) is presented to show the correlation between onshore and offshore records of the transgressive ravinement surface (Figure 6 ). Two additional crosssections, L41 AND L23, respectively from the north and south parts of the study area, are included in Supplemental Materials (Supplemental Figures 1,2). Those cross-sections include reflections from low-stand or latest Pleistocene erosional surfaces that predate the Holocene transgressive sequences (Twichell and Cross, 2001; Twichell et al., 2010; Herb, 2000; Vanderburgh et al., 2010).

The onshore transgressive ravinement surface in DHoyst (dated at $\sim 8.3 \mathrm{ka}$ ) is correlated to the offshore ravinement surface that substantially deepens to at least -50 m elevation within $5.0 \mathrm{~km}$ distance offshore of the present shoreline in seismic profile L37 (Figure 6). The vertical seismic profile stations (S) represent locations on the seismic profile (line) that are chosen arbitrarily at about a two kilometer spacing, starting at the easternmost end of the profile at S1. The overlying (post-transgressive) sediment deposit at S3 (5.7 km offshore distance in L37) is estimated to be $22 \mathrm{~m}$ in thickness. The onshore post-ravinement shelf deposit in DHoyst (-6.3 to $-21.6 \mathrm{~m}$ elevation) contains relatively uniform fine sand (Supplemental Table 3) and fine sand is assumed for the inner-shelf facies in the offshore profile stations S1, S2 and S3 along the seismic profile L37. The compositions of the prograded beach and dune ridge sand deposits in the onshore 
drill holes are not distinguishable from the underlying shelf facies, except by ground penetrating radar reflections, which do occur in the beach and dune facies but not in the shelf facies (Jol et al., 1996; Peterson et al., 2010a,b). In this article the beach and dune sand are not differentiated from shelf sand in onshore drill hole stratigraphic sections, but the $0 \mathrm{~m}$ elevation datum generally separates the overlying beach facies from the underlying shelf facies in the onshore cross-section areas (Peterson et al., 2010b).

\subsection{Inner-shelf cross-sections from twelve transects in the CRLC system}

Twelve inner-shelf cross-sections are constructed from combinations of onshore drill hole records, offshore seismic profiles and shallow vibracores (Figure 3). The four northernmost cross-sections (L3, L5, L7, L11) are characterized by little to no offshore deposition above the transgressive ravinement surface (Supplemental Figure 3). Three cross-sections from the north-central area of the CRLC system (L41, L46, L37) show a southward deepening of the transgressive ravinement surface and correspondingly thicker overlying inner-shelf deposits (5$30 \mathrm{~m}$ thickness) relative to the northern cross-sections (Figure 7 and Supplemental Figure 4). The northernmost and shallowest part of the transgressive ravinement surface in the three north-central transects occurs in cross-section L41, where basal deposit radiocarbon ages of 6.8, 8.0 and 5.1 ka, respectively, were obtained in vibracore sites V502 (-14.5 m elevation), V503 (-35 m elevation), and V504 (-43.6m elevation) (Supplemental Table 4). Sea level estimated ages for the corresponding 
transgressive surface are 1-5 ka older than the reported basal deposit radiocarbon ages, suggesting time lags in net sedimentation after ravinement by the marine transgression.

Two cross-sections from the south-central area of the CRLC system (L36 and L33) show a further southward deepening of the transgressive ravinement surface and thickening of overlying inner-shelf deposits with increasing proximity to the ancestral Columbia River valley (Figure7 and Supplemental Figure 5). The innershelf deposits reach $\sim 50 \mathrm{~m}$ thickness above the transgressive ravinement surface at V306 and V307, respectively, at distances of 8.7 and 11.1 from the present shoreline in cross-section L33. The most landward drill hole in cross-section L33, DHmchu, terminated in well-sorted fine sand at -9 m elevation, which occurs below a bay mud (6.0 ka in radiocarbon age). The basal fine sand (39.3 ka in age) (Smith et al., 1999) was deposited well above the low-stand paleo-sea level, about -50 m elevation at 40 ka (Pirazzoli, 1993). The late Pleistocene fine sand deposit in DHmchu is interpreted to be an eolian dune deposit that originated from eolian transport across the emerged inner-shelf during latest Pleistocene time, as found for similar latePleistocene dunes in the central Oregon coast (Figure 1) (Peterson et al., 2007). However, the thickness/elevation of the dune sand in DHmchu is trivial by comparison to the very-large late-Pleistocene dunes in the central Oregon coast.

Three cross-sections from the southernmost area of the CRLC system (L24, L23, L19) show shallowing depths of the transgressive ravinement surface and thinning of overlying inner-shelf deposits with distance south of the ancestral Columbia River valley (Figure 7 and Supplemental Figures 6 and 7 ). The inner-shelf 
deposits overlying the transgressive ravinement surface in the southernmost crosssection (L19) thin substantially seaward the inner-most shelf even though ravinement surface depths deepen from $-36.5 \mathrm{~m}$ elevation to $-56.3 \mathrm{~m}$ elevation over the intervening $7.0 \mathrm{~km}$ distance. In this regard the southernmost cross-section (L19), located south of the ancestral Columbia River valley (Figure 3) differs from cross-section L33, located north of the Columbia River valley, where thick innershelf deposits overlie a deep part of the transgressive ravinement surface. Samples in vibracores ( $5 \mathrm{~m}$ depth subsurface) at sites V104 and V105, respectively, in cross-section L23 provided radiocarbon dates of 5.4 and 5.7 ka (Supplemental Table 4). The onshore drill hole DHsuns demonstrates a vertical accumulation of about 10 $\mathrm{m}$ of inner-shelf sand facies during the time interval 2.6-4.3 ka.

\section{DISCUSSION}

Analyses of sand grain size and heavy mineral source indicators in modern beach samples and shelf vibracore samples (1-5 m depth subsurface) from the CRLC inner-shelf (Figures 4 and 5) establish the longshore extent ( $160 \mathrm{~km})$ and acrossshelf extent $(\sim 10 \mathrm{~km})$ of the active Columbia River littoral system, between Point Grenville to the north and Tillamook Head to the south. The substantial overlaps between mean sand grain sizes in modern beach deposits (sample means 0.15-0.27 $\mathrm{mm}$ ) and in offshore vibracore samples from the inner-shelf (sample means 0.13$0.25 \mathrm{~mm}$ ) demonstrate a broad interconnected littoral zone (0-50 $\mathrm{m}$ water depth) in the high-wave-energy CRLC system (Supplemental Tables 2 and 3). Onshore drill 
hole sections in inner-shelf facies (1-30 $\mathrm{m}$ in thickness and 0-8 ka in age) serve as proxies for offshore post-ravinement inner-shelf deposits (1-50 $\mathrm{m}$ in thickness and 1-12 ka in estimated age) (Figure 7) in terms of sand source (Columbia River bedload or fine sand discharge) and textural composition ( $\geq 90$ weight percent fine sand). In this section we address the conditions of inner-shelf geometry, postravinement sea level rise, fluvial sand discharge, and changing wind/wave stress climates that permitted such substantial thicknesses of littoral sand to have been deposited in the high-wave-energy CRLC inner-shelf during the last 12 ka.

\subsection{Onshore and offshore geology of the CRLC system}

The coastline of the CRLC study area is embayed at the mouths of the Columbia River, Willapa Bay, and Grays Harbor estuaries (Figure 8). The incised valleys of the Columbia River and Chehalis River originate east of the Coast Range and connect with the Astoria and Grays Canyon heads at the shelf break. The lowstand surface indicates that the Columbia River traversed the shelf to the head of the Astoria Canyon (Figure 9) (Twichell et al., 2010). The small Willapa River occurs in an 'over-fit' valley that might have sourced east of the Coast Range in latest Tertiary time and might have connected with either the Willapa or Guide Canyon during past Quaternary low-stands. Across-shelf river valley incisions locally lowered the lowstand surfaces in the inner-shelf, particularly in the vicinity of the ancestral Columbia River valley (see further discussion about downcut inner-shelf topography below). 
The three inland river valleys formed by the Columbia, Willapa and Chehalis rivers are associated with recessed inland surface exposures of late Tertiary formations (Figure 8) between transects L11 and L19 (Walsh et al., 1987; Dragovich et al., 1987). Indurated bedrock of possible Miocene age (Logan, 2003) is exposed in the modern sea cliff at 5-8 m elevation in transect L5. Bedrock is exposed offshore in the sea floor of the innermost-shelf in transects L3, L5 and L7, as imaged by sidescan sonar (Twichell and Cross, 2001). The only bedrock exposed in sea and bay cliffs in the central area of the CRLC is from a small erosional remnant of resistant basalt at North Head, located north of the of the Columbia River mouth. The exposures of bedrock in sea cliffs at the north and and south bounding headlands, respectively Point Grenville and Tillamook Head, are not due to differential Quaternary tectonic uplift, which is relatively uniform $(\sim 1.0 \mathrm{~m} / 10,000 \mathrm{yr})$ along the CRLC coastline (Peterson and Cruikshank, 2014). Pleistocene estuarine terraces of locally anomalous height ( $\sim 40 \mathrm{~m}$ elevation) are mapped 1.5-2.5 km landward of the present shoreline in transects L41 and L46 (Walsh et al., 1987). They are possibly associated with a localized fault zone (McCrory et al., 2002). Even these highest Quaternary terraces do not show any evidence of late Miocene/Pliocene 'bedrock' units at the base of the abandoned sea cliffs or in shallow drill holes (reaching -10 to $-20 \mathrm{~m}$ elevation) in the prograded beach plains that front the uplifted terraces (Herb, 2000; Vanderburgh et al., 2010).

In summary, Quaternary fluvial downcutting of resistant bedrock in the central and southern areas of the CRLC inner-shelf contrasts with shallow bedrock surfaces in the northern area of the CRLC system. It is not known to what extent the 
river valleys might have been guided by pre-existing structural controls. At the regional scale it is apparent that the three river valleys occur in the lowest part of the uplifted North Coast Range (300-500 m ridge crest elevations) between the Olympic Mountains (1000-1500 m ridge crest elevations) located $\sim 75 \mathrm{~km}$ north of Grays Harbor and the Tillamook Mountains (700-900 m ridge crest elevations) located $\sim 75 \mathrm{~km}$ south of the Columbia River (Figure 1). The geometric complexity of the CRLC inner-shelf is not unique in the study region, as onshore incised river valleys and offshore bedrock banks, bights and pinnacles are present along the coast and in inner-shelf settings located north and south of the CRLC study area (McManus, 1964; Runge, 1966).

Evidence of latest Pleistocene alluvial/outwash deposits (Walsh et al., 1987) crossing the non-incised northernmost inner-shelf during low-stand conditions are shown by 1) onshore gravelly sand deposits in sea cliff exposures (5-20 m elevation) at DHmocl (transect L3) and DHroos (trasnsect L5) (Supplemental Figure 3) and 2) offshore re-worked gravelly sand deposits in the inner- and mid-shelf, located north of transect L11 (Twichell and Cross, 2001). No surface gravel deposits are reported for the inner- and mid-shelf areas south of transect L11, likely due to burial by post-transgressive mid- to late-Holocene deposits.

Outer-shelf gravelly sand deposits (-150 to -200 m elevation) are reported for much of the CRLC shelf study area (Twichell et al., 2010). The age(s) and depositional settings(s) of the relict outer-shelf gravels are not reported.

\subsection{Geometries of low-stand surfaces and the transgressive ravinement surface}


Reconstructed contours of the late-Pleistocene low-stand surfaces and the Holocene transgressive ravinement surface are shown for the CRLC inner-shelf (Figure 9) (Twichell et al., 2010; Vanderburgh et al., 2010). Offshore transgressive ravinement surface contours generally coincide with the low-stand surface contours, except in deeply incised valleys of the Columbia and Chehalis Rivers. Preravinement sediment accumulation in the inner-shelf was largely restricted to the deeply incised river valleys (Peterson and Phipps, 1992; Twichell et al., 2010; Peterson et al., 2013). Here we focus on post-ravinement accommodation space in the inner-shelf.

The deeper contours of the transgressive ravinement surface $(-30$ to $-80 \mathrm{~m}$ elevation) show paleo-shoreline orientations that generally trend slightly west of north in the CRLC inner-shelf (Figure 9). The $-40 \mathrm{~m}$ elevation ravinement surface contour in the northernmost area of the inner-shelf has an average trend of $350^{\circ}$. The trend of the $-40 \mathrm{~m}$ contour changes to $335^{\circ}$ in the north-central area of the inner-shelf, between Willapa Bay and Grays Harbor and to $345^{\circ}$ in the northernmost area, located between Grays Harbor and Point Grenville. Such paleo-shoreline and inner-shelf orientations could have reduced northward littoral drift by paleo-storm wind stress and surf that arrived from the southwest during lower sea level stands. The paleo-shoreline orientation in the southernmost area of the CRLC inner-shelf is much less oblique to true north, averaging about $355^{\circ}$.

The transgressive ravinement surface and the modern depositional surface in the CRLC inner-shelf are plotted for the 12 transect cross-sections (Figure 10). 
The transgressive ravinement surface in the northernmost area of the inner-shelf (transects L3, L5, L7 and L11) is relatively shallow in across-shelf gradient, reaching only $-25 \mathrm{~m}$ elevation at $5.0 \mathrm{~km}$ distance from the present shoreline. It is to be noted that the shallowest parts of the transgressive ravinement surface, in transects L3, L5 and L7, are associated with seafloor bedrock exposures in the northernmost innershelf (Supplemental Figure 3). The transgressive ravinement surface from the central and southern transects (L37, L36, L33, L24, L23 and L19) is steeper in across-shelf gradients, ranging from $-45 \mathrm{~m}$ to $-60 \mathrm{~m}$ elevation at $5.0 \mathrm{~km}$ distance from the present shorelines (Table 1). The transect (L33) displays the deepest transgressive ravinement surface, located just north of the ancestral Columbia River Valley.

The modern depositional surface in the 12 inner-shelf transects is relatively uniform in across-shelf gradients, ranging from -20 to $-30 \mathrm{~m}$ in elevation at distances of $5.0 \mathrm{~km}$ from the present shoreline (Figure 10). The two exceptions are 1) transect L19, which shows a deeper modern surface depth of -40 m elevation at $5.0 \mathrm{~km}$ distance from the present shoreline, and 2) transect L24, which shows a shallower modern surface at $-15 \mathrm{~m}$ elevation at $5.0 \mathrm{~km}$ distance from the modern shoreline. Regarding the anomalous deepening of the modern surface in transect L19, either recent sediments are not reaching the seaward part of transect L19 or recent deposits are being eroded and transported north of the southernmost transect in the CLRC inner-shelf. In contrast, the anomalous shallowing in transect L24 likely reflects abundant sand supply to the inner-shelf that is located offshore of the Columbia River mouth (Figure 3). The northernmost transects L3, L5 and L7 are 
not included in this surface deposit analysis, due to the lack of deposition above the bedrock and/or gravel transgressive surface in the northernmost area of the CRLC inner-shelf (Figure 8).

\subsection{Accommodation space in the CRLC inner-shelf}

The differences in elevation between the transgressive ravinement surface and the overlying depositional surface in the transect cross-sections (Figure 7) represent the post-ravinement accumulation of fine sand, derived from Holocene Columbia River sand discharge to the CRLC system. Plots of transgressive ravinement surface elevations and corresponding inner-shelf deposit thicknesses are shown for representative offshore distances $(0 \pm 1 \mathrm{~km}, 5 \pm 1 \mathrm{~km}, 10 \pm 1 \mathrm{~km})$ from the present shoreline (Figure 11). At the intermediate distances of $5 \pm 1 \mathrm{~km}$ offshore of the present shorelines the deepest part of the transgressive ravinement surface (41 to -55 m elevation) accumulated 21-39 meters of sand, whereas the shallowest part of the ravinement surface (-17 to -22 m elevation) yielded only $0-4 \mathrm{~m}$ of vertical sand accumulation. Wave and current energies in the middle inner-shelf of the northernmost transects (L3, L5, L7 and L11), with a shallow transgressive ravinement surface of $>-23 \mathrm{~m}$ elevation, were too high (shallow) to permit longterm sand deposition. As previously noted, transect L19 accumulated thinner postravinement deposits ( $\sim 10 \mathrm{~m}$ thickness) in the middle area of the inner-shelf, relative to nearby transects (L23, L24, L33) that accumulated $\geq 20 \mathrm{~m}$ deposit thicknesses near the ancestral Columbia River valley. 
The post-ravinement deposition in the CRLC transects (Figure 7) represents the accommodation space that was filled by fine sand in the inner-shelf. The filled accommodation space, as measured for transect cross-section areas (combined onshore and offshore), normalized to $1.0 \mathrm{~m}$ alongshore distance and $1.0 \mathrm{~km}$ acrossshelf distance, are plotted against corresponding mean gradient (slope \%) of the transect transgressive ravinement surface (Table 1; Figure 12). Whereas shallow gradients of $0.36-0.41 \%$ yielded $\sim 0-3400 \mathrm{~m}^{3} \mathrm{~m}^{-1} \mathrm{~km}^{-1}$ of normalized accommodation space the steeper gradients of $0.44-0.63 \%$ yielded $13,800-33,000$ $\mathrm{m}^{3} \mathrm{~m}^{-1} \mathrm{~km}^{-1}$ of sand-filled accommodation space. The greater inner-shelf accommodation space in the central and southern transects resulted from their steeper transgressive ravinement surface gradients. The gradient(s) of the modern depositional surface in the CRLC inner-shelf ( $\sim 0.38 \%$ ) (Figure 2 Part A) likely represent the depositional gradient limit for available accommodation space of fine sand under recent conditions of available sand grain size, sea level, and wave/windstress in the CRLC system. Smaller gradients would likely 1) export sand onshore, leading to upper-shoreface progradation, 2) export sand along-shelf and out of the local littoral system, and/or 3) aggrade the local inner-shelf vertically with increasing sea level rise.

\subsection{Post-ravinement sedimentation rates in the CRLC inner-shelf}

Long-term post-ravinement sedimentation rates in the CRLC inner-shelf are based on age and elevation differences between the transgressive ravinement 
surface and radiocarbon dated samples in deposits that are at or just above the ravinement surface (Figure 7; Supplemental Table 4). We compare estimated ages of the transgressive ravinement surface using 1) relative sea level ages for corresponding ravinement surface elevations and 2) radiocarbon dates of basal deposits within $\pm 1.5 \mathrm{~m}$ of the ravinement surface (Figure 13). It was found that the ravinement surface radiocarbon ages substantially post-date the sea level curve ages of transgressive ravinement in the northern transects (L3, L7 and L11), where the post-ravinement deposits are very thin. In the central and southern transects the transgressive ravinement deposit ages are closer to the sea level curve ages of ravinement, however discrepancies between the two methods are still on the order of 1-4 ka. Radiocarbon dates from deposits that were truncated by the transgressive ravinement surface are expected to pre-date the truncating ravinement ages. Deposits that immediately overlie the transgressive ravinement surface could include remobilized materials that would also pre-date ravinement ages. However, the time lags between transgressive ravinement and net deposition, as shown by the northern transects, could represent the greatest errors in dating the transgressive ravinement surface by nearest sample radiocarbon dates. In this article we follow Twichell et al. (2010) in using paleo-sea level curve ages for ravinement surface ages of corresponding elevations. Potential errors associated with continued ravinement surface erosion 1-2 m below mean sea level (MSL) are small relative to rates of sea level rise in early and middle Holocene time (Figure $2 \mathrm{C}$ ).

In this research we use corresponding sea level ages of the bounding transgressive ravinement surface and much younger radiocarbon dated samples 
from overlying deposits in corresponding sites to estimate long-term sedimentation rates in the central and southern inner-shelf transects. The sea level curve age estimates of the corresponding ravinement surfaces represent maximum ages of the onset of sedimentation, due to potential delayed deposition, and are therefore conservative for calculating sedimentation rates. Estimated long-term sedimentation rates for sections spanning 4-13 ka in age from the central and southern transects of the CRLC inner-shelf are compiled in Table 2. The long-term sedimentation rates range from 0.4 to $4.4 \mathrm{~m} \mathrm{ka}^{-1}$ in offshore transects that contain a continuous cover of post-ravinement deposits. The lowest offshore sedimentation rates presented here (0.4-0.9 $\left.\mathrm{m} \mathrm{ka}^{-1}\right)$ occur in the northern transect (L41) which contained a thin cover ( $\sim 5 \mathrm{~m}$ thickness) of Holocene sand deposits (Figure 7$)$. The highest offshore sedimentation rates (3.0-4.4 m ka-1) occur in transects L33, L24, and L23 were post-transgressive deposits are the thickest (25-50 m thick) (Figure 7). These transects contain the deepest areas of the transgressive ravinement surface, relative to across-shelf position, due to their locations on either side of the deeply-incised ancestral Columbia River valley. Long-term sedimentation rates in the onshore shelf facies (1.0-4.1 $\left.\mathrm{m} \mathrm{ka}^{-1}\right)$ that were sampled in drill holes are similar to their offshore counterparts in corresponding across-shelf transects. Due to the long time span sections that were dated above the offshore transgressive ravinement surface it is not possible to discriminate between factors other than ravinement surface gradient that might have influenced long-term sediment rates in the inner-shelf. Such additional factors might include changing rates of 1) sea level 
rise, 2) landward transgression of the shoreline, and 3) changing rates of river sand supply to the littoral zone, among others.

Recent short-term sedimentation rates in the CRLC inner-shelf are available from offshore vibracores that span the latest Holocene (Kaminsky, 2006). These short-term records are associated with conditions of 1) a low rate of net-sea level rise ( $\sim 0.75 \mathrm{~m} \mathrm{ka}^{-1}$ ) (Figure 2 Part C), 2) stable or net-prograding shorelines (Woxell, 1998), and 3) substantial sand discharge from the Columbia River (5-6 $\mathrm{x} 10^{6} \mathrm{~m}^{3} \mathrm{yr}^{-1}$ ) (Peterson et al., 2013). The latest Holocene interval spans multiple cycles of coseismic subsidence and interseismic uplift (5 cycles in $2.5 \mathrm{ka}$ ) in the study region (Peterson et al., 2010a). In this article we select sedimentation intervals ( $\geq 1.0 \mathrm{ka}$ ) that include at least two interseismic-uplift cycles. Short-term sedimentation rates from latest Holocene sections (0-3.0 ka) in offshore transects are shown in Table 3. Recent short term sedimentation rates in the inner-shelf range from 0.1 to $4.1 \mathrm{~m} \mathrm{ka}^{-1}$. The mean short-term sedimentation rate $\left(1.9 \pm 1.5 \mathrm{~m} \mathrm{ka}^{-1}\right.$, $\mathrm{N}=14$ ) in the selected core sites is significantly higher then the rate of net-sea level rise, during the last $2.5 \mathrm{ka}$.

The locally high rates of recent vertical accumulation in some shallow sites in the innermost-shelf are thought to reflect relatively rapid sedimentation from upper-shoreface progradation in latest-Holocene time (Peterson et al, 2010a,b). However, the high recent short-term rates demonstrated in some deeper sites $(\geq 15$ $m$ water depth) are apparently the result of recent sand deposition in offshore areas that are located down-drift of the ebb-tide deltas at the mouths of the Columbia River and Grays harbor (Figure 14). For example, maximum recent short-term 
sedimentation rates $\left(2.3-4.1 \mathrm{~m} \mathrm{ka}^{-1}\right)$ occur in the northern transect L11, located north of the Grays Harbor ebb-tide delta, and in transects 33 and 36, located north of the Columbia River ebb-tide delta (Figure 3). Near-surface prehistoric radiocarbon dates in sites L36V302 (0.7 ka at -33.2 m elevation) and L33V306 (0.5 ka at -33.2 m elevation) (Supplemental Table 4) indicate that the recent high rates of sedimentation in transects L36 and L33, located north of the Columbia River mouth, are prehistoric in age. Those high rates of prehistoric sedimentation are not the result of jetty construction, offshore dredge disposal and/or other historic impacts to the CRLC system (Gelfenbaum and Kaminsky, 2010).

It is not known whether the anomalous low-rate of recent sedimentation in L23V105 at -25 m elevation (0.1 m ka-1) reflects very-low sediment input or recent erosion and northward transport of the deeper inner-shelf deposits at the southern end of the CRLC system (Kaminsky, 2006; Peterson et al., 2010b). In either case, the generally low rates of recent vertical accumulations in the deeper water depths of transects L24 and L23, appear to reflect diminished sediment supply to those offshore areas, due to their positions located south of the Columbia River mouth and ebb tide delta.

\subsection{Paleo-wind stress and wave climates in the CRLC inner-shelf}

In this project we use modeled paleo-wind stress and deep water wave directions in the CRLC inner-shelf to help constrain interpretations of sand transport directions during the MIS1 marine transgression (0-18 ka). We assume 
that fine sand transport in the inner-shelf is dominated by major winter storm wind and storm wave conditions (Sternberg, 1986; Kachel and Smith, 1986). Paleo-wind stress and assumed corresponding wave directions for winter months (Dec., Jan., Feb.) during the last $21 \mathrm{ka}$ are modeled at 3 ka time steps for the study region from global climate models (Figure 15) (Alder and Hostetler, 2015). The wind stress vectors (bearing and velocity) are based on estimated paleo-sea level pressure gradients that are down sampled from the GENMOM model which combines the GENESISv3 atmospheric model (Alder et al., 2011) and MOMv2 oceanic model (Pacanowski, 1996). The coupled atmospheric and oceanic model outputs are verified at $0 \mathrm{ka}, 6 \mathrm{ka}$, and $21 \mathrm{ka}$ (LGM) time intervals, using terrestrial and marine climate reconstructions (Alder and Hostetler, 2015). The GENMOM model is used to simulate eight equilibrium time slices at 3000-year intervals for the last 21,000 years.

We assume that maximum along-shelf geostrophic currents and associated across-shelf downwelling in the study area are forced by coastal winds, whereas the winter storm surf directions could be the products of both coastal winds and more seaward storm centers in the NE Pacific Ocean. Under pre-industrial (PI=modern) conditions the dominant coastal winter wind stress and surf directions are from the southwest. These modeled winter wind directions show little variation until about 6 ka, but they become increasingly south-southwesterly by 9 ka, and become nearly due south by $12 \mathrm{ka}$. The roles that changing paleo-wind stress and wave directions play in 1) diverting the remobilized pre-Holocene shelf deposits north of the CRLC system (12-9 ka) and then 2) largely trapping Holocene Columbia River sand in the 
CRLC system (6-0 ka) are discussed in terms of marine transgression and paleoshoreline orientations below.

\subsection{Geologic history of CRLC inner-shelf sand deposition}

In this section we summarize the geologic history of sand transport and deposition in the CRLC inner-shelf during the marine isotope stage 1 (MIS1) marine transgression. During latest Pleistocene time the Columbia River exported fine sand to the continental slope via the Astoria Canyon (Figure 1) (Griggs and Kulm, 1969; Brunner et al., 1999; Normark and Reid, 2003; Lopes and Mix, 2009). Negligible dune sand was available for eolian transport across the emerged continental shelf during low-stand conditions in the CRLC system. The only late-Pleistocene dune deposits that were identified in onshore drill holes were from a very-short section (9 to -10.5 m elevation) dated at 39 ka in DHmchu (Figure 7), located just north of the Columbia River mouth (Herb, 2000). Onshore summer winds did occur during low-stand conditions in the study area, as evidenced by late-Pleistocene coastal loess deposits in the region (Figure 15). The lack of late-Pleistocene coastal dune development in the central and southern areas of the CRLC system reflects a lack of available sand in the inner-shelf during low-stand conditions. The lack of inner-shelf sand deposits is attributed to the downcutting and off-shelf transport of fine sand by the Columbia River and its lateral tributaries during low-stand conditions. In contrast, the northern area of the CRLC inner-shelf was covered by pro-glacial fluvial outwash deposits. The coarse-grained outwash deposits reach 10-15 $\mathrm{m}$ in 
thickness in sea cliff exposures at transects L3 and L5 (Supplemental Figure 3), but are assumed to have thinned with increasing distance across the inner-shelf. Posttransgressive remnants of the outwash deposits are evident in inner-shelf gravels in transects L3, L5 and L7 in the northernmost area of CRLC inner-shelf (Figure 8).

During the early part of the MIS1 transgression (9-15 ka), when sea level was between $-100 m$ and $-30 m$ elevation, the southerly storm surf (Figure 15) eroded unconsolidated outwash deposits during transgressive ravinement and transported the late-Pleistocene sand northward, out of the CRLC system (Figure 16 Part A). The lack of pre-Holocene outwash sand mineralogy in 1) the CRLC innershelf surface deposits (Figure 5), 2) the modern beach deposits (Figure 4) and 3) the onshore shelf facies (0-8 ka) (Supplemental Table 4), attests to the effective northward transport of pre-Holocene sand deposits out of the CRLC system during the early- to mid-Holocene transgression. The same net-northward littoral drift transported some Holocene Columbia River sand northward along paleo-shorelines and the paleo- inner-shelf (-80 to -50 m elevation) to the paleo-Grays Harbor embayment at DHwest1 by 10 ka (Figures 3 and 15).

During middle- to late-Holocene time (after $9 \mathrm{ka}$ ) sea level rise and in-filling of the Columbia River ancestral valley had terminated off-shelf transport of sand in the Astoria Canyon. The Holocene Columbia River sand discharged to the marine side was contained in the middle- and inner-shelf areas. During this same time the orientations of the winter storm wind stress and waves became less oblique to the northwest trending paleo-shorelines (Figures 15 and 21), thereby more effectively trapping Columbia River sand in the CRLC system (Figure 16 Part B). Gravel, eroded 
from retreating sea cliffs in the northernmost CRLC shorelines, was transported south by traction transport along paleo-beaches to the Grays Harbor tidal inlet/shelf facies in DHoyst1 and DHwest1 (Supplemental Table 4) while fine sand was being transported northward in the inner-shelf by combined oscillatory-wave resuspension and northward-geostrophic flow (Figure 2 Part B) (Sternberg, 1986; Katchel and Smith, 1986). Differing slightly from the Katchel and Smith (1986) model the Holocene Columbia River sand was largely trapped in the inner-shelf ( $\leq$ $50 \mathrm{~m}$ water depth) where surface sand deposits are hypersthene-rich (Figure 5) (Scheidegger, et al., 1971; Venkatarathnam and McManus, 1973). The long term rates of post-ravinement shelf sedimentation in the central and southern inner-shelf areas (1.3-4.4 $\left.\mathrm{m} \mathrm{ka}^{-1}\right)$ average $3.2 \mathrm{~m} \mathrm{ka}^{-1}(\mathrm{n}=14)$. The mean rate of long-term sedimentation is about one quarter $(\sim 25 \%)$ of the mean rate of sea level rise $(12.2$ $\left.\mathrm{m} \mathrm{ka}^{-1}\right)(\mathrm{n}=14)$ for the same time intervals (Table 2). Sea level rose faster in the early and middle Holocene time than the rate of Columbia River sand supply to the CRLC inner-shelf.

By late-Holocene time $(\sim 5 \mathrm{ka})$ the rate of sea level rise had substantially decreased $\left(\sim 1 \mathrm{~m} \mathrm{ka}^{-1}\right)$ (Figure 2 Part C). Discharge of Columbia River sand exceeded the slow rates of sea level rise, leading to the filling of available accommodation space in the central and southern areas of the CRLC inner-shelf. The orientations of winter storm wind stress and waves became less oblique to the northwest trending shorelines (Figure 15). Though a net-northward drift prevailed in the inner-shelf, the ongoing supply of Holocene Columbia River sand to the littoral zone was effectively trapped in the nearshore and barrier/beach system 
(Figure 16 Part C). The filling of available inner-shelf accommodation space in late Holocene time led to 1) the reduction of the inner-shelf depositional gradient and 2) the net onshore wave transport of littoral sand to prograding beach plains and barrier spits during the last 3-5 ka. The shallow bedrock surfaces and netnorthward littoral drift in the northernmost area of the CRLC system prohibited significant deposition in the northern transects L3, L5, and L7. However, recent short-term sedimentation rates in the central and southern transects (mean rate 1.9 $\mathrm{m} \mathrm{ka}^{-1}$ ) demonstrate that the inner-shelf was continuing to fill at, or locally-faster, than the recent rates of relative sea level rise $\left(\sim 1 \mathrm{~m} \mathrm{ka}^{-1}\right)$ during late Holocene time (Table 3, Figure 14). The relatively high rates of recent vertical accumulation in the CRLC inner-shelf are attributed to a prograding upper-shoreface and localized deposition at and/or downdrift of ebb tide deltas at the mouths of the Columbia River and Grays Harbor.

\subsection{Post-ravinement sediment budget in the CRLC inner-shelf}

Post-ravinement sand deposits in the CRLC inner-shelf (offshore and onshore transect cross-sections as defined in Figure 7 and Supplemental Figures 3-7) total 2.48x1010 $\mathrm{m}^{3}$ (Table 4). Twichell et al. (2010) estimate $79 \mathrm{~km}^{3}\left(7.9 \times 10^{10} \mathrm{~m}^{3}\right)$ for the entire Holocene fill volume in the middle- and inner-shelf, including the offshore incised River valleys. The smaller volume reported in this article $\left(2.48 \times 10^{10} \mathrm{~m}^{3}\right)$ is limited to the post-ravinement deposition in the CRLC inner-shelf. The accumulation rate of inner-shelf facies deposited above the ravinement surface for the last $\sim 12 \mathrm{ka}$ 
is about $2.07 \times 10^{6} \mathrm{~m}^{3} \mathrm{yr}^{-1}$. We do not further resolve this long-term total volume rate either spatially or temporally in this paper due to a lack of deep radiocarbon dates from the offshore sections. The CRLC inner-shelf fill rate is about one third of the sand discharge estimated for the Columbia River $\left(5-6 \times 10^{6} \mathrm{~m}^{3} \mathrm{yr}^{-1}\right)$ for the last $8 \mathrm{ka}$ (Peterson et al., 2013) or just slightly lower than the modern sand throughput rate of $2.7 \times 10^{6} \mathrm{~m}^{3} \mathrm{yr}^{-1}$ as modeled by Kaminsky et al., (2001) and reported by Gelfenbam and Kaminsky (2010). Apparent early-historic inner-shelf erosion to supply sand to the adjacent beaches (Ruggerio et al., 2016) is a temporary effect of post-subsidence rebound, and interseismic uplift following the AD1700 coseismic subsidence (Peterson et al., 2010a). The long-term response of the inner-shelf to abundant sand supply from the Columbia River has been net vertical accretion.

The CRLC inner-shelf accumulation rate is expected to be conservative for total shelf fill rates because it does not include 1) early-and middle-Holocene fill rates for the mid-shelf and 2) pre-ravinement fill deposits in incised valleys that were preserved below the inner-shelf transgressive ravinement surface (Twichell and Cross, 2001; Twichell et al., 2010). The CRLC inner-shelf accumulation rate does not account for sand transported north of Point Grenville during early- to middleHolocene time (Figure 16), nor does it account for the abrasion of weak lithic sand grains to form very-fine size sand and silt grains that were transported seaward to the mid-shelf. Nevertheless, the post-ravinement fill accumulation rate in the innershelf during the last $\sim 12 \mathrm{ka}$ is substantially greater than the accumulation rate of the beach plains and barrier spit facies in the CRLC system $\left(\sim 0.34 \times 10^{6} \mathrm{~m}^{3} \mathrm{yr}^{-1}\right)$ during the last $\sim 5 \mathrm{ka}$ (Linde, 2014). The fill rates of the two tidally-dominated 
estuaries, Willapa Bay and Grays Harbor (Figure 1), are currently under investigation by some of these authors, however, it is clear that the Columbia River sand source and the inner-shelf sand sink are likely to be the dominant regional drivers of littoral sand dynamics in the CRLC system during the Holocene marine transgression.

The potential role(s) of inner-shelf sand sinks in impacting beach erosion from predicted future global sea level rise (Vermeer and Rahmstorf, 2009) have likely been under-appreciated in some high-wave-energy littoral systems. Assuming a complete filling of additional inner-shelf accommodation space from a net sea level rise of $1.0 \mathrm{~m}$ in the CRLC system, the increased inner-shelf accommodation space (1.0 m depth, $10.0 \mathrm{~km}$ across-shelf width and $126.5 \mathrm{~km}$ along-shelf length) (Table 4) could provide a net-sink for a volume of $1,265 \times 10^{6} \mathrm{~m}^{3}$ of fine littoral sand. This is equivalent to at least 200 years of prehistoric sand discharge from the Columbia River. Without the Columbia River input of sand, the potential inner-shelf sand sink could result in $10,000 \mathrm{~m}^{3}$ of beach sand erosion per alongshore meter of shoreline or about $1.0 \mathrm{~km}$ of net beach retreat (10 m average vertical profile) in the CRLC system following a net sea level rise of $1.0 \mathrm{~m}$. This a substantial increase (> 100\%) relative to the traditional equilibrium profile methods (Bruun, 1962) and assumed inter-decadal depths of closure (20 m) that were used by Doyle (1996) and Peterson et al. (2000) for the study area.

\section{CONCLUSIONS}


The transgressive ravinement surface in onshore drill hole sections and adjacent offshore seismic reflection profiles in the CRLC inner-shelf can be stratigraphically correlated based on elevation, slope, continuity and radiocarbon dating. The relative thicknesses of onshore post-ravinement shelf facies $(1-30 \mathrm{~m}$ thick) under prograded beach plains and barrier spits are proportionally similar to adjacent offshore post-ravinement shelf deposits (1-50 m thick) as imaged in the seismic reflection profiles. The bounding ages of 1) the transgressive ravinement surface, based on corresponding sea level ages and 2) overlying near-surface deposits, based on radiocarbon dates, provide long-term sedimentation rates for both onshore and offshore inner-shelf facies. The inner-shelf deposit thicknesses and estimated long-term sedimentation rates are positively correlated to transgressive ravinement surface depths. The post-ravinement deposits represent available accommodation spaces filled primarily by fine sand in the high-waveenergy inner-shelf setting. Recent short-term sedimentation rates $\left(1.9 \pm 1.5 \mathrm{~m} \mathrm{ka}^{-1}\right)$ are locally higher than recent rates of net-sea level rise $\left(\sim 1 \mathrm{~m} \mathrm{ka}^{-1}\right)$, indicating 1$)$ upper shoreface progradation in some innermost-shelf sites and 2) localized accumulation of sand deposits located downdrift (northward) of large ebb tide deltas at the mouths of the Columbia River and Grays Harbor.

The lack of significant shoreward pre-Holocene shelf sand transport to the accreting barriers and beach plains in the CRLC resulted from four conditions. These conditions were a general lack of Columbia River sand accumulation in the preHolocene shelf, presumably due to off-shelf transport through the Astoria Canyon. A strong net-northward export of outwash sand deposits in the northern inner-shelf 
was due to a northward directed wind and wave stress in early Holocene time. Postravinement accommodation space in the inner-shelf resulted from post-ravinement sea level rise during middle to late Holocene time. Abundant sand supply to the littoral zone, from throughput of Columbia River sand, combined with high wave energy, geostrophic flow, and under-welling flow resulted in the dispersal of littoral sand along the CRLC inner-shelf. The inner-shelf could not supply pre-Holocene sand to the accreting CRLC barriers and beach plains in latest Holocene time because the inner-shelf was itself a large net sink for littoral sand during middle- to late-Holocene time.

Two factors contributed to the substantial sand accommodation space that persisted in the inner-shelf of the CRLC system during the middle- to-late Holocene marine transgression. They include 1) possible structural controls on the positions of large antecedent river valleys in the CRLC study area and the incised and/or embayed low-stand surfaces that lead to relatively steep ravinement surface gradients associated with the ancestral river valleys and 2) 10-50 m of postravinement relative sea level rise in most of the inner-shelf sites. The available accommodation space was largely in-filled within the CRLC inner-shelf area by seaward transport of sand across the inner-shelf and by limited alongshore dispersal of sand in the inner-shelf. The availability of post-ravinement accommodation space in the CRLC inner-shelf was made apparent because of the large volume of fine sand that was discharged from the Columbia River throughout the marine transgression. Such increases in inner-shelf accommodation space following post-ravinement sea level rise likely occurred in other high-wave-energy 
inner-shelves. However, a lack of fluvial sand input to the littoral zone in some other shelf settings left the available accommodation space unfilled during the transgression, and therefore, not recognized or measured. The CRLC system, which does have a large sand input from the Columbia River, demonstrates that such postravinement increases in sand accommodation space can occur in high-energy innershelf settings following post-ravinement sea level rise.

The significance of available accommodation space in the present CRLC inner-shelf, and possibly in other high-wave-energy inner-shelves, is relevant to potential impacts from 1) regional sand management practices and 2) future sea level rises resulting from predicted global warming. The volumes of inner-shelf accommodation space that are increased by modest rates of sea level rise can potentially dwarf the small onshore reservoirs of sand in some beach and barrier systems. With sufficient wind and wave stress energy in some coastal settings the onshore beach sand reservoirs could be displaced to fill increasing accommodation space in the inner-shelf, following future sea level rises. Unlike the CRLC system that has substantial river sand discharge to help replace the potential loss of onshore sand reservoirs to future offshore sand sinks, some sand-limited littoral systems could experience substantial shoreline retreat following future sea level rises and net-offshore sand transport to fill inner-shelf sand sinks.

\section{Acknowledgements}


James Phipps provided early inspiration for these studies of sediment partitioning and accommodation space in the Columbia River littoral cell system. Mark Newman-Bennett and Andrew Zachary assisted with onshore auger drilling in the CRLC beaches, beach plains and barrier spits. David Percy analyzed early LIDAR data for onshore drill site elevations. Dave Qualman operated the surf zone vibracore system and assisted with core logging and grain-size analysis of the surf zone vibracores. Kenneth Parolisky operated the offshore seismic reflection system that was used to profile the CRLC inner-shelf transects. VeeAnn Cross processed the seismic data and helped compile the maps of shelf deposits. Marie Ferland operated the offshore vibracore system and assisted George Kaminsky with core logging and radiocarbon sampling of the CRLC shelf vibracores. This work was funded by the U.S. Geological Survey, Coastal and Marine Geology Program, under the South West Washington Coastal Erosion Project, Co-op \#1434-HQ-96-AG-01612 from 19962001.

\section{References}

Alder, J.R., and Hostetler, S.W., 2015. Global climate simulations at 3000-year intervals for the last 21000 years with the GENMOM coupled atmosphereocean model. Climate of the Past 11, 449-471.

Alder, J. R., Hostetler, S. W., Pollard, D., and Schmittner, A., 2011. Evaluation of a present-day climate simulation with a new coupled atmosphere-ocean model 
GENMOM. Geoscience Model Dev. 4, 69-83.

Allan, J.C., and Komar, P.D., 2002. Extreme storms in the Pacific Northwest coast during the 1997-98 El Niño and 1998-99 La Niña. Journal of Coastal Research 18, 175-193.

Ballard, R. L. 1964. Distribution of beach sediment near the Columbia River: University of Washington, Department of Oceanography, Technical Report No. 98,82 p.

Baker, D., Peterson, C., Hemphill-Haley, E., and Twichel, D., 2010. Holocene Sedimentation in the Columbia River Estuary, Marine Geology 27, 83-95.

Berg, J. W., King, J.M., and Carlson, P R., 1966. Seismic reflection studies of buried channels off the Columbia River. Ore Bin 28, 145-150.

Brunner, C. A., Normark W.R., Zuffa, G.G., and Serra, F., 1999. Deep-sea sedimentary record of the late Wisconsin cataclysmic floods from the Columbia River. Geology 27, 463-466.

Bruun, P., 1962. Sea-level rise as a cause of shoreline erosion, Journal of Waterways Harbors Division, American Society of Civil Engineers 88, 117-130. 
Buijsman, M.C., Sherwood, C.R., Gibbs, A.E., Gelfenbaum, G., Kaminsky, G.M., Ruggiero, P., and Franklin, J., 2003. Regional Sediment Budget Analysis of the Columbia River Littoral Cell, USA: Analysis of Bathymetric- and TopographicVolume Change, U.S. Geological Survey Open-File Report OF 02-281, 103 p.

Chin, J.K., Karl, H.A., and Maher, N.M., 1997. Shallow subsurface geology of the continental shelf, Gulf of the Farallones, California, and its relationship to surficial seafloor characteristics. Marine Geology 137, 251-269.

Daniels, R.C., 2001. Datum conversion issues with LIDAR spot elevation data. Photogrammetric Engineering and Remote Sensing 67, 735-740.

Dean, R.G., 1991. Equilibrium beach profiles: characteristics and applications, Journal of Coastal Research 7, 53-84.

Doyle, D.L., 1996. Beach response to subsidence following a Cascadia subduction zone earthquake along the Washington-Oregon coast. M.S. Thesis, Portland State University, Portland, Oregon, 113 p.

Dragovich, J.D., Logan, R.L., Schasse, H.W., Walsh, T.J., Lingley, Jr., W.S., Norman, D.K., Gerstel, W.J., Lapen, T.L.J. Schusgter E., and Meyers, K.D., 1987. Geologic Map of Washington- Northwest Quadrant. Washington Division of Geology and Earth Resources Geologic Map GM-5072P. and map 1:250,000 scale. 
http://wadnr.s3.amazonaws.com/Publications/ger_gm50_geol_map_nw_wa_ 250k.pdf, Accessed September 17, 2015

Gates, E.B., 1994. The Holocene sedimentary framework of the lower Columbia River basin. M.S. Thesis, Portland State University, Portland, Oregon, 210 p.

Gelfenbaum, G., and Kaminsky, G.M., 2010. Large-scale coastal change in the Columbia River littoral cell: An overview. Marine Geology 273, 1-10.

Griggs, G.B., and Kulm, L.D., 1969. Glacial marine sediments from the Northwest Pacific. Journal of Sedimentary Petrology 39, 1142-1148.

Herb, A.A., 2000, Holocene stratigraphy and sediment volumes for the Columbia River littoral cell, Pacific Northwest, USA. M.S. Thesis, Portland State University, Portland, Oregon, 186 p.

Jol, H.M., Smith, D.G., Meyers, R.A., 1996, Digital ground penetrating radar (GPR): An improved and very effective geophysical tool for studying modern coastal barriers (examples for the Atlantic, Gulf and Pacific coasts, U.S.A.). Journal of Coastal Research, 12, 960-968.

Kachel, N.B., and Smith J.D., 1986. Geologic impact of sediment transporting events 
on the Washington continental shelf. In Knight R.J., and McLean J.R., (eds)

Shelf Sands And Sandstones. Canadian Society of Petroleum Geologists, Memoir II. P. 145-162.

Kaminsky, G.M., 2006. Shoreface behavior and equilibrium. PhD Thesis, University of Sydney, 633 p.

Kaminsky, G.M., Kaminsky, G.M., Buijsman, M.C., and Ruggiero, P., 2001. Predicting shoreline change at decadal scale in the Pacific Northwest, USA. Proceedings of the 27th International Conference on Coastal Engineering. American Society of Civil Engineers, pp. 2400-2413.

Logan, R.L., 2003. Geologic map of the Copalis Beach 1:100,000 Quadrangle, Washington. Washington Division of Geology and Earth Resources Open-File Report 2003-16. Map 1:100,000 scale and geologic unit key.

Linde, T., 2014. Regional database analysis of dated prehistoric shorelines to establish sand partitioning in late Holocene barriers and beach plains of the Columbia River littoral cell, Washington and Oregon, USA. M.S. Thesis, Portland State University, 86 p.

Lopes, C., and Mix, A.C., 2009. Pleistocene megafloods in the northeast Pacific. Geology 37, 79-82. 
McCrory, P.A., Foster, D.S., Danforth, W.W., and Hamer, M.R., 2002. Crustal deformation at the leading edge of the Oregon Coast Range Block, Offshore Washington (Columbia River to Hoh River). Earthuake Hazards of the Pacific Northwest Coastal and Marine Regions. U.S. Geological Survey, Professional Paper 1661-A. Published online http://geopubs.w.usgs.gov/profpaper/pp1661-A/ Accessed October 1, 2014.

McManus D.A., 1964. Major bathymetric features near the coast of Oregon, Washington, and Vancouver Island. Science 38, 65-82.

Meyers, R.A., Smith, D.G., Jol, H.M., and Peterson, C.D., 1996, Evidence for eight great earthquake-subsidence events detected with ground-penetrating radar, Willapa barrier, Washington. Geology 2, 99-102.

Nittrouer, C.A., 1978. The process of detrital sediment accumulation in a continental shelf environment: An examination of the Washington shelf. PhD Thesis, University of Washington, 242 p.

Normark, W.R., and Reid, J.A., 2003. Extensive deposits on the Pacific plate from late Pleistocene North American lake outbursts. Journal of Geology 111, 617-637.

Pacanowski, R. C., 1996. MOM 2 Version 2.0 (Beta) Documentation: User's Guide and 
Reference Manual, Technical Report 3.2, NOAA GFDL Ocean Group, GFDL, Princeton, New Jersey, 329 pp.

Peterson, C.D., and Cruikshank, K.M., 2014. Quaternary tectonic deformation, Holocene paleoseismicity, and modern strain in the unusually-wide coupled zone of the central Cascadia margin, Washington and Oregon, USA and British Columbia, Canada. Journal of Geography and Geology. 6: no 3. 32 p. PDF. Published online: www.ccsenet.org/jgg.

Peterson, C.D., Darienzo, M.E., Hamilton, D., Pettit, D.J., Yeager, R.K., Jackson, P.L., Rosenfeld, C.L., and Terich, T.A., 1994. Cascadia Beach-Shoreline Data Base, Pacific Northwest Region, USA. Oregon Department of Geology and Mineral Industries Open-File Report 0-94-2, 29 p., and 3 Electronic Database Files.

Peterson, C.D., Doyle, D.L., and Barnett, E.T., 2000. Coastal flooding and beach retreat from coseismic subsidence in the central Cascadia margin, USA. Environmental and Engineering Geology 6 255-269.

Peterson, C.D., Gates, E.B., Minor, R. and Baker, D.L., 2013. Accommodation space controls on the latest Pleistocene and Holocene (16-0 ka) sediment size and bypassing in the Lower Columbia River Valley: A large fluvial-tidal system in Oregon and Washington, USA. Journal of Coastal Research 29, 1191-1211. 
Peterson, C.D., Phipps, J.B., 1992. Holocene sedimentary framework of Grays Harbor Basin, Washington. Society of Economic Paleontologists and Mineralogists Special Publication 48, 273-285.

Peterson, C.D., Stock, E., Hart, R., Percy, D., Hostetler, S.W., Knott, J.R., 2009. Holocene coastal dune fields used as indicators of net littoral transport: West Coast, USA. Geomorphology 116, 115-134.

Peterson, C.D., Stock, E., Price, D.M., Hart R., Reckendorf, F., Erlandson, J.M., and Hostetler, S.W., 2007. Ages, Distributions, and Origins of Upland Coastal Dune Sheets in Oregon, USA. Geomorphology 91, 81-102.

Peterson, C.D., Jol., H.M., Vanderburgh, S., Phipps, J.B., Percy, D., and Gelfenbaum, G., 2010a. Dating of late-Holocene shoreline positions by regional correlation of coseismic retreat events in the Columbia River littoral cell. Marine Geology $273,44-61$.

Peterson, C.D., Vanderburgh, S., Roberts M.C., Jol, H.M., Phipps, J.P., and Twichell, D.C., 2010b. Composition, age, and depositional rates of Holocene shoreface deposits under barriers and beach plains of the Columbia River littoral cell, USA. Marine Geology 273, 62-82. 
Pilkey, O.H., Young, R.S., Riggs, S.R., Smith, A.W.S., Wu, H., and Pilkey, W.D., 1993. The concept of shoreface profile of equilibrium: a critical review. Journal of Coastal Research 9, 255-278.

Pirazzoli, P.A., 1993. Global sea-level changes and their measurement. Global and Planetary Change 8, 135-148.

Rankin, D.K. 1983, Holocene geologic history of the Clatsop plains foredune ridge complex: M.S. Thesis. Portland State University, 175 p.

Ruggiero, P., Kaminsky, G.M., Gelfenbaum, G., Cohn, N., 2016. Morphodynamics of progading beaches: A synthesis of seasonal-to-century-scale observations of the Columbia River littoral cell. Marine Geology 376, 51-68.

Ruggiero, P., Kaminsky, G.W., Komar, P.D., and McDougal, W.G., 1997. Extreme waves and coastal erosion in the Pacific Northwest. In Proceedings of Waves '97 ASCE pp. 947-961.

Runge, J.E., Jr., 1966., Continental shelf sediments, Columbia River to Cape Blanco, Oregon. PhD Thesis. Oregon State University, 143 p.

Scheidegger, K.F., Kulm, L.D., and Runge, E.J., 1971. Sediment sources and dispersal 
patterns of Oregon continental shelf sands. Journal of Sedimentary Petrology $41,1112-1120$.

Scheidegger, K.F., and Phipps, J.B., 1976. Dispersal patterns of sands in Grays Harbor estuary, Washington. Journal of Sedimentary Petrology 46, 163-166.

Sherwood, C. R., Jay, D. A., Harvey R. B., Hamilton, P., and Simenstad, C. A., 1990. Historical changes in the Columbia River estuary. Progress In Oceanography $25,299-352$.

Short, A.D., 1987. Modes, timing, and volume of Holocene cross-shore and aeolian sediment transport, Southern Australia. Coastal Sediments 1987, 19251937.

Smith J.D., and Hopkins, T.S., 1972. Sediment transport on the continental shelf off of Washington and Oregon. In Swift, D., Duane and Pilkey, O., (Eds) Shelf Sediment Transport. Dowdon, Hutchinson and Inc., Stroudsburg, USA., p. 143-180.

Smith, D.G., Meyers, R.A., and Jol, H.M., 1999. Sedimentology of an upper meso tidal (3.7 m) Holocene barrier, Willapa Bay, SW Washington, U.S.A. Journal of Sedimentary Research, Section B: Stratigraphy and Global Studies 69, 12901296. 
Sternberg, R.W., 1986. Transport and accumulation of river-derived sediment on the Washington continental shelf, USA. Journal of the Geological Society, London $143,945-956$.

Sternberg, R.W., and Larsen L.H., 1976. Frequency of sediment movement on the Washington continental shelf: A Note. Marine Geology 21, M37-M47.

Thom, B.G., 1984. Transgressive and regressive stratigraphies of coastal sand barriers in eastern Australia. Marine Geology 56, 137-158.

Tillotsen, K.J., and Komar, P.D., 1997. The wave climate of the Pacific Northwest (Oregon and Washington): A comparison of data sources. Journal of Coastal Research 13, 440-452.

Twichell, D.C., and Cross, V.A., 2001. Holocene evolution of the southern Washington and northern Oregon shelf and coast: Geologic discussion and GIS data release, US Geological Survey, Open File Report 01-076, 27 p., and CDRom disk.

Twichell, D.C., Cross, V.A., Peterson, C.D., 2010. Partitioning of sediment on the shelf offshore of the Columbia River littoral cell. Marine Geology 273, 11-31. 
U.S. Geological Survey, 2015. Shaded Relief Base Map http://www.arcgis.com/home/webmap/viewer.html?webmap=360fbdd4da 8b441298524ebb80c28360 Accessed September 19, 2015

Vanderburgh, S., Roberts, M.C., Peterson, C.D., Phipps, J.B., and Herb, A, 2010. Holocene transgressive and regressive deposits of the Columbia River littoral cell barriers and beach plains. Marine Geology 273, 32-43. doi:10.1016/j.margeo.2010.02.002

Venkatarathnam, K., and McManus, D.A., 1973. Origin and distribution of sands and gravels on the northern continental shelf of Washington. Journal of Sedimentary Petrology 43, 799-811.

Vermeer M., and Rahmstorf, S., 2009. Global sea level linked to global temperature. Proceedings of the National Academy of Sciences, 106, 21527-21532. www.pnas/org/cgi/doi/10.1073/pnas.0907765106. Accessed October 1, 2010.

Walsh, T.J., Korosec, M.A.,. Phellips W.M., Logan, R.L., and Schasse, H.W., 1987. Geologic Map of Washington-Southwest Quadrant. Washington Division of Geology and Earth Resources Geologic Map GM-34 1987 10p. and map 1:250,000 scale 
http://wadnr.s3.amazonaws.com/Publications/ger_gm34_geol_map_sw_wa_ 250k.pdf, Accessed September 17, 2015.

Woxell, L.K., 1998. Prehistoric beach accretion rates and long-term response to sediment depletion in the Columbia River littoral system, USA. M.S. Thesis, Portland State University, 206 p.

Figure Captions

Figure 1: Regional map showing the Columbia River Littoral Cell (boxed), located between Point Grenville in Washington (WA) and Tillamook Head in Oregon (OR). The Columbia and Chehalis Rivers are antecedent through the Coast Range (triangles). The Columbia River is antecedent through the Cascade volcanic arc (triangles). The Columbia River littoral cell (CRLC) is divided into four subcells, which are separated by tidal inlets at the Columbia River mouth, Willapa Bay and Grays Harbor. Smaller coastal rivers, including the Queets, Hoh, and Quillayute Rivers occur north of the CRLC. The shelf break (dotted line) at -200 m elevation NAVD88 shows indentations at several submarine canyons, including the Astoria Canyon, located near the south end of the study area. The Strait of Juan De Fuca (JDF) dissects the inner-shelf north of the study area. Map coordinates are in latitude and longitude (degrees) and UTM-10T (kilometers). 
Figure 2: Part A. Across-shelf surface profiles (west-east) were redrafted from Kaminsky (2006), as compiled by Buijsman (2003). Three profiles (NS01, NS04 and NS05) are averaged across several kilometer-wide bathymetric swaths, which were selected from recent surveys (1990-2000). One profile is taken from sesismic line (SL23) as completed in 1997 and reported by Twichell and Cross (2001). See Part B for location of cross-shelf profiles in the four subcells of the CRLC. Part B. Bathymetric map of the CRLC shelf (0 to -140 m elevation at $20 \mathrm{~m}$ contour depth spacing) showing extent of surface deposits dominated by fine sand (stippled pattern $>75 \%$ sand), as redrafted from Nittrouer (1978). Predicted directions of sand transport (arrows) are based on modeled wave oscillatory currents, geostrophic flow and down-welling, resulting from winter storm waves and wind shear stress, as redrafted from Kachel and Smith (1986). Part C. Relative sea level curve (0-16 ka) reported for the CRLC study area (Peterson et al., 2010b).

Figure 3: CRLC study area with selected beach plain/barrier spit drill holes (lettered), selected ravinement depth profiles (solid circles) along seismic reflection lines (L), selected vibracore sites (open circles) and surface grab samples (open boxes). Modern shelf bottom contours are in $20 \mathrm{~m}$ intervals of elevation NAVD88. Ebb tide deltas (ETD) are shown offshore of the tidal inlets of the Columbia River, Willapa Bay and Grays Harbor estuaries. Position coordinates and data sources for the onshore drill holes, surf zone vibracore sites and offshore vibracore sites are provided in Supplemental Table 1. Seismic profile line (L) positions are provided in 
Twichell and Cross (2001). Map coordinates are in longitude and latitude $\left(^{\circ}\right)$ and UTM-10N kilometer northings (N) and eastings (E).

Figure 4: Regional map of beach sample sites (solid circles) and corresponding plots of beach width $(\mathrm{km})$, mean sand grain size $(\mathrm{mm})$ and sand provenance indicators, hypersthene to augite (ratio). The CRLC system (CRLC study area) extends on either side of the Columbia River mouth to the dashed lines at Point Grenville to the north and Tillamook Head to the south. Map coordinates are UTM (10TN) in km intervals northing (N) and easting (E). Data are from Supplemental Table 2.

Figure 5: Textural and sand source compositional data for subsurface samples in offshore vibracores (one sample per vibracore) are plotted for five across-shelf transects. Four variables, including bottom water depth, percent sand, sand grain size and sand heavy mineralogy are plotted against across-shelf distanced (km on the X axis) for each of the 5 transects (L11, L41, L36, L33, L23). Modern shelf bottoms (deposit water depths) are in m elevation NAVD88 ranging from $0 \mathrm{~m}$ (top of Y axis) to - $100 \mathrm{~m}$ depth (bottom of Y axis). Deposit percentages of sand (\%) are plotted from 0.0 percent (bottom of Y axis) to 100 percent (top of Y axis). Deposit sand grain sizes (means) are plotted from $0.4 \mathrm{~mm}$ (top of $\mathrm{Y}$ axis) to $0.0 \mathrm{~m}$ (bottom of Y axis). Columbia River sand source mineralogy (hyp/aug ratio) is plotted from 1.0 (top of Y axis) to 0.0 (bottom of Y-axis). Data are from Supplemental Table 3. 
Figure 6: Correlations of transgressive ravinement surface (red bold line) in onshore drill holes (DHoyst and DHbayr) with dated deposits (arrows) (Vanderburgh et al., 2010) and offshore seismic reflection profile (L37) (Twichell and Cross, 2001). The vertical datum is in elevation (m) NAVD88. Onshore distances are in negative kilometers and offshore distances are in positive kilometers relative to the modern shoreline (Shore) at $0 \mathrm{~km}$ distance. Locations of offshore seismic profile stations (S1, S2, S3) in profile L37 and onshore drill holes (DHoyst, DHbayr) are shown in Figure 3.

Figure 7: Inner-shelf cross-sections from three CRLC cross-sections (L41, L33, L23) (Figure 3) show the shallow transgressive ravinement surface (dotted line) and modern depositional surface (bold line). The vertical datum is elevation (m) NAVD88. Representative elevation/age data are shown for paleo-sea levels (0-10 ka) in the CRCL system, as selected from Figure 2 Part C. Drill hole (DH) and vibracore (V) site position data are in Supplemental Table 1. Position and elevation data for modern- and paleo-sea cliffs (solid circle) and for seismic profile stations (S) are in Supplemental Table 4.

Figure 8: Onshore/offshore geology map for the CRLC system showing relations between onshore major river valleys (Columbia, Willapa, Chehalis) and offshore submarine canyon heads (Astoria, Willapa, Guide, Grays)(McManus, 1964). Modern shelf bottom contours are in m elevation NAVD88. Onshore drill holes (solid squares) and offshore seismic profiles (numbered lines) are shown relative to 1) 
Tertiary (T) bedrock exposures (east of dashed line), 2) Quaternary (Q) deposits (west of dashed line) and 3) inner-shelf fine sand (>75\%) east of dotted line to the shoreline. Bedrock is exposed in the northernmost inner-shelf area (dashed line). Relict gravelly-sand patches (stippled) are shown at the northern end of the CRLC inner-shelf and in the outer-shelf, located seaward of the mid-shelf mud belt. Major river valleys are redrafted from modern DEM maps (USGS, 2015). Submarine canyons are named (McManus, 1964). Tertiary bedrock exposures are redrafted from Walsh et al. (1987) and Dragovich et al. (1987). Offshore exposures of Tertiary bedrock and relict Pleistocene gravels are redrafted from Twichell et al. (2010).

Figure 9. Overlay maps of low-stand surface elevations (dotted line contours) and transgressive ravinement surface elevations (solid line contours). Ravinement surface contours (20 m intervals elevation NAVD88) generally overlie low-stand surface contours, except in deeply incised river valleys. Paleo-shoreline orientations (black bars) are based on local parallels to the $-40 \mathrm{~m}$ ravinement surface contour and range from $335^{\circ}$ to $355^{\circ}$ north.

Figure 10: Profiles of the transgressive ravinement surface and the modern depositional surface are shown for transects (L) in the CRLC inner-shelf and prograded barriers and beach plains, relative to the modern shoreline $(0 \mathrm{~km}$ distance). Elevations (m) are shown relative to the NAVD88 datum. Data are from cross-sections shown in Supplemental Figures 3-7. Transects L3, L5, and L7 are not 
shown under modern depositional surfaces due to bedrock and/or relict-gravel at the modern sea floor in those offshore transects.

Figure 11: Plot of inner-shelf deposit thickness versus transgressive ravinement surface elevation in across-shelf transects at $0 \pm 1 \mathrm{~km}, 5 \pm 1 \mathrm{~km}$ and $10 \pm 1 \mathrm{~km}$ interval distances offshore of the present shoreline. Onshore inner-shelf deposits are measured for thickness below 0 m elevation NAVD88 (Peterson et al., 2010b). Data are compiled from Supplemental Figures 3-7 and Supplemental Table 4. Transects that extend less than $9.0 \mathrm{~km}$ in offshore distance (L3, L5, L7, L19) are not included in the $10 \pm 1 \mathrm{~km}$ distance plot.

Figure 12: Plot of transgressive ravinement surface gradient (slope \%) versus filled post-ravinement mean accommodation space $\left(x 1000 \mathrm{~m}^{3} \mathrm{~m}^{-1} \mathrm{~km}^{-3}\right)$ normalized to 1.0 $\mathrm{m}$ distance alongshore and $1.0 \mathrm{~km}$ distance across-shelf in transects in the CRLC inner-shelf. One anomalous data point representing the maximum filled accommodation space is from cross-section L24 (Figure 3), which is located both offshore of the ancestral Columbia River valley and in the Columbia River ebb tide delta. Data are from Table 1.

Figure 13: Plot of transgressive ravinement surface ages based on 1) relative paleosea level ages (ka) for the corresponding ravinement surfae elevations and 2) radiocarbon dating (ka) of nearest deposits (within $\pm 1.5 \mathrm{~m}$ of the ravinement surface elevations). The dashed line represents a hypothetical direct age 
correspondence between ravinement surface ages measured by relative sea level and radiocarbon dating. Such a relation did not occur in the data set from the CRLC inner-shelf deposits. Data are from Supplemental Table 4.

Figure 14: Plots of long-term sedimentation rates (squares) and recent short-term sedimentation rates (circles) in onshore sites (open) and offshore sites (solid) in the CRLC inner-shelf relative to distance north and south of the ancestral Columbia River valley (dashed line at $0 \mathrm{~km}$ distance). Data are from Tables 2 and 3.

Figure 15: Modeled paleo-sea level pressure and wind/wave stress during winter months (DJF) for the CRLC region (0-21 ka) at 3 ka time step intervals, starting with modern (pre-industrial) time step of 0 ka (Alder and Hostetler, 2015). Modeled sea level pressures $995-1025 \mathrm{hPa}$ are used to estimate the dominant directions and velocities $\left(\mathrm{m} \mathrm{s}^{-1}\right)$ of wind vectors (arrows) along the coast and to offshore distances of $1000-2000 \mathrm{~km}$ in the NE Pacific Ocean. The study area is centered in the solid black rectangle in the pre-industrial time slice (PI) in upper left panel. See Alder and Hostetler (2015) for details about model components and verification.

Figure 16: Summary figure of geologic history of shelf erosion, transport and deposition. Marine transgression (shaded) is shown for three time intervals, including Part A (12-15 ka), Part B (6-9 ka), and Part C (0-3 ka) relative to ravinement surface contours (20 m intervals elevation NAVD88). Wind/wave stress vectors (sharp arrows) are shown for the three time intervals. Net sand transport 
directions and relative magnitudes (blunt arrows) are shown for corresponding time intervals. Geographic features (Part A) include from north to south, Point Grenville (PG), Grays Harbor (GH), Willapa Bay (WB), Columbia River (CR) and Tillamook Head (TH). Inner-shelf transects (L) are numbered in Part C. 


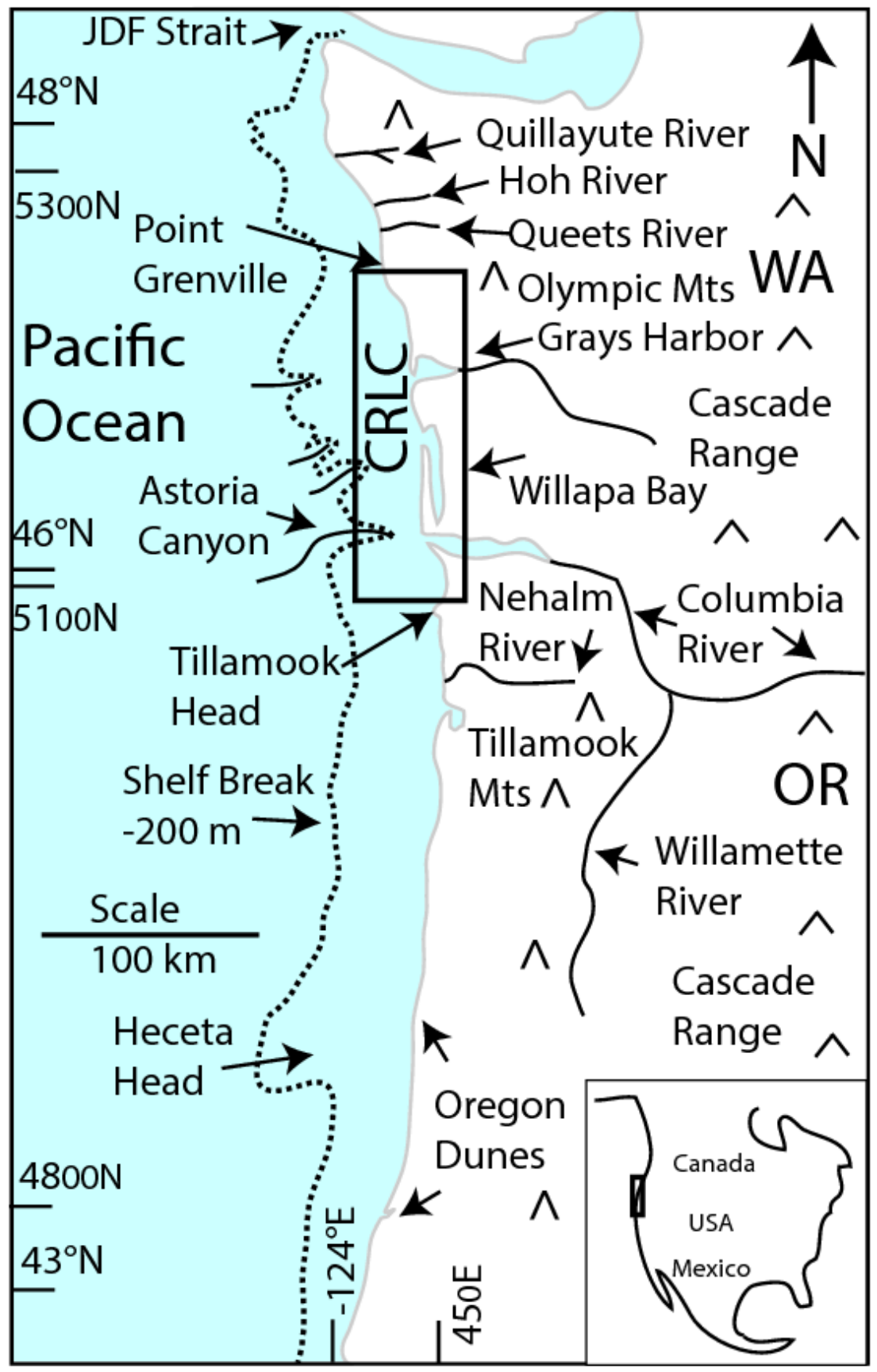

Figure 1 


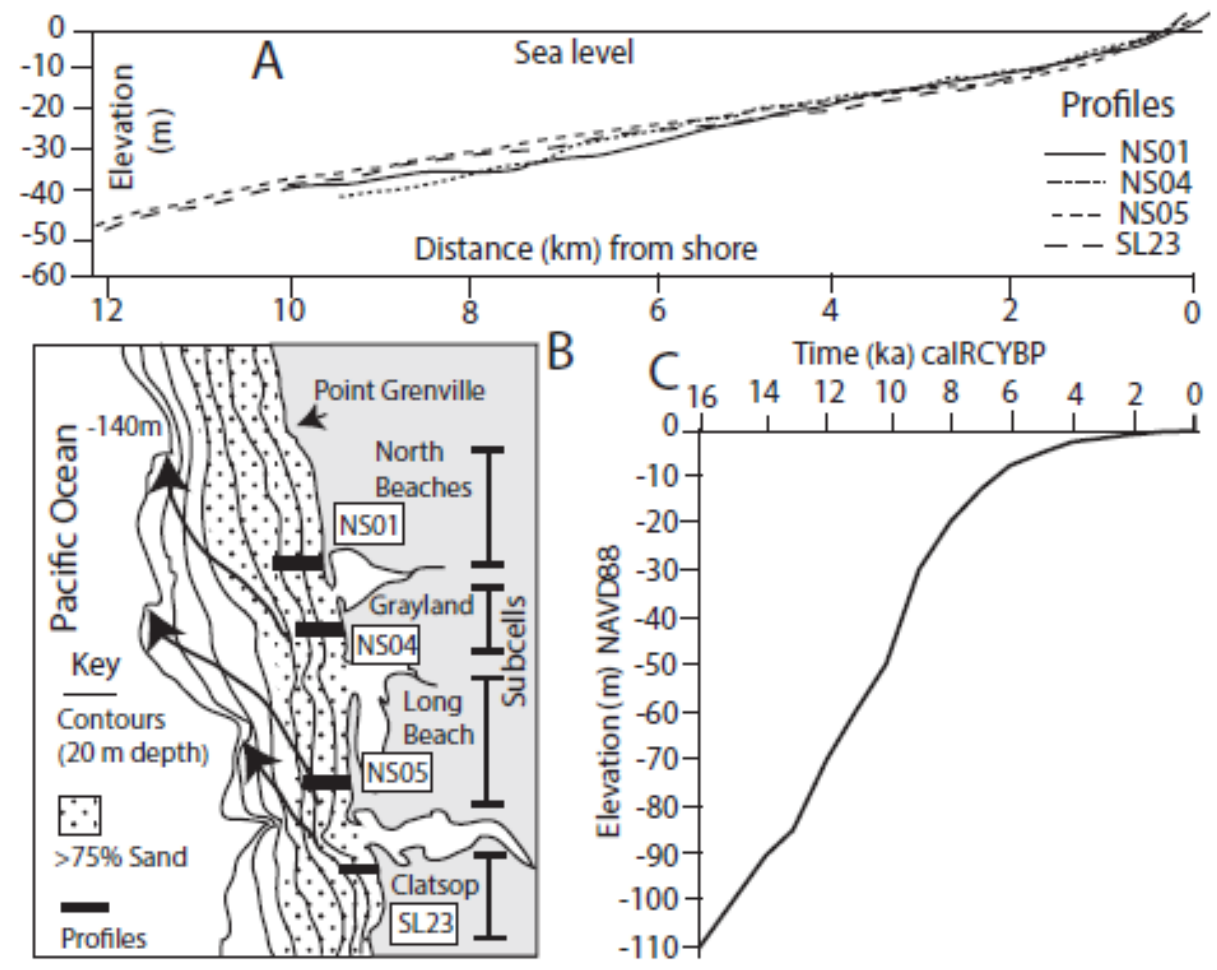

Figure 2 


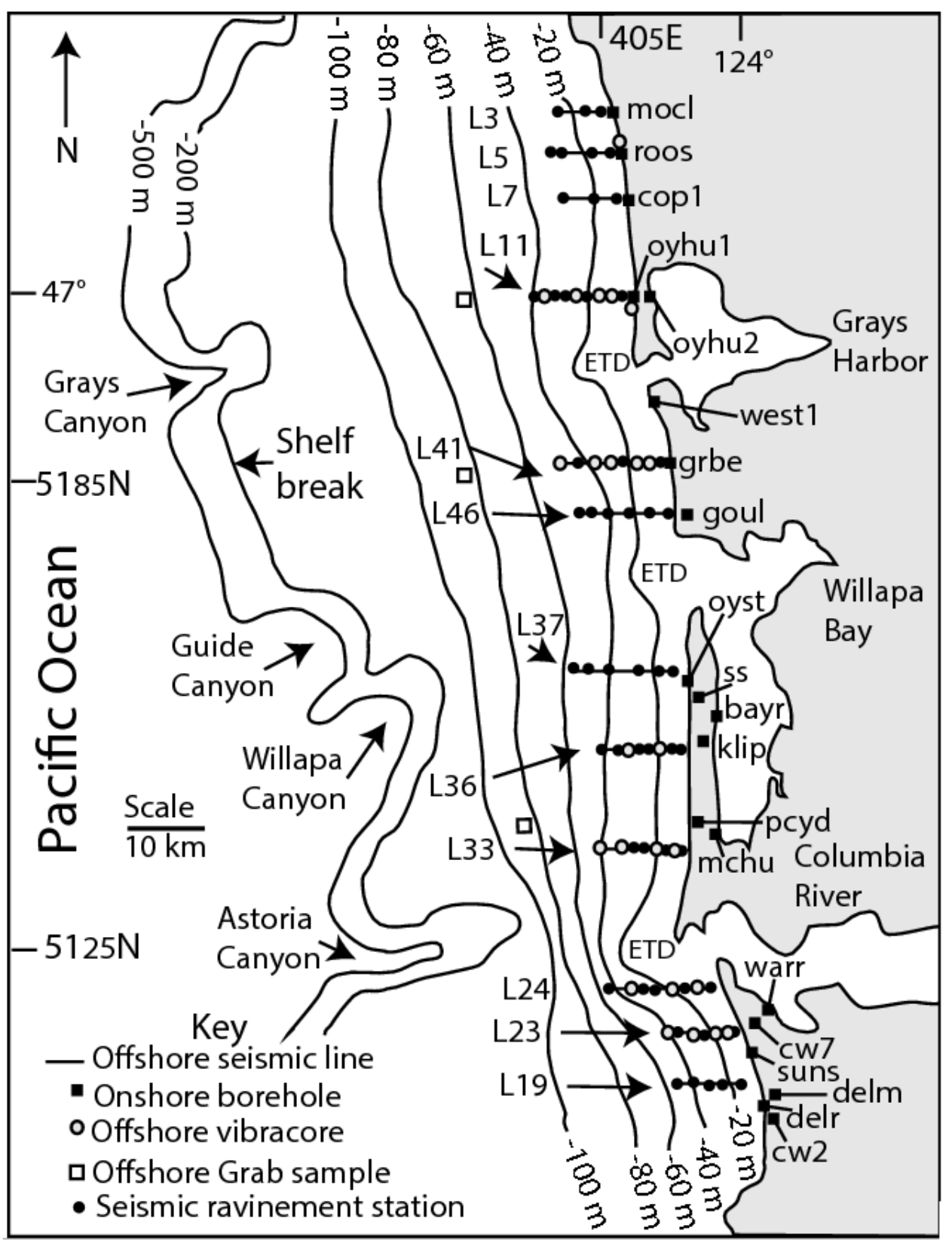

Figure 3 


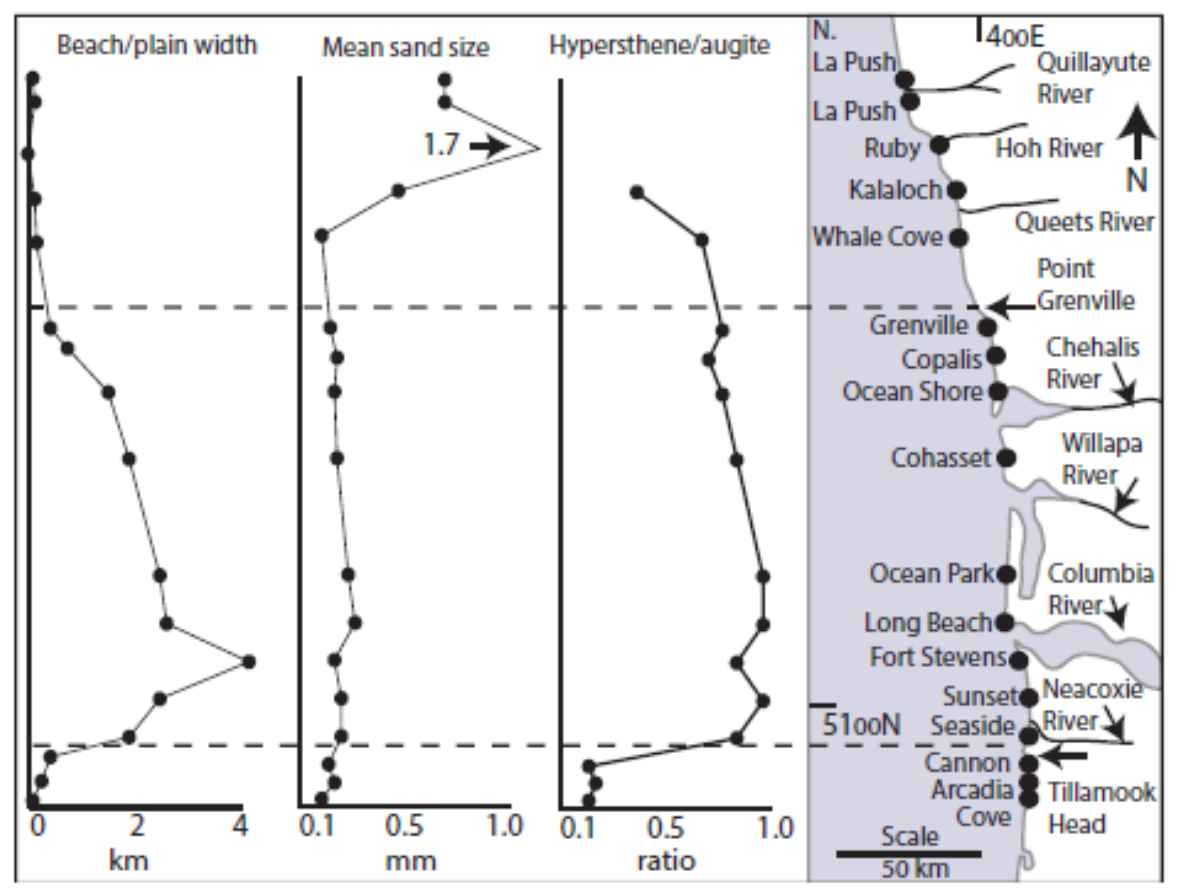

Figure 4 


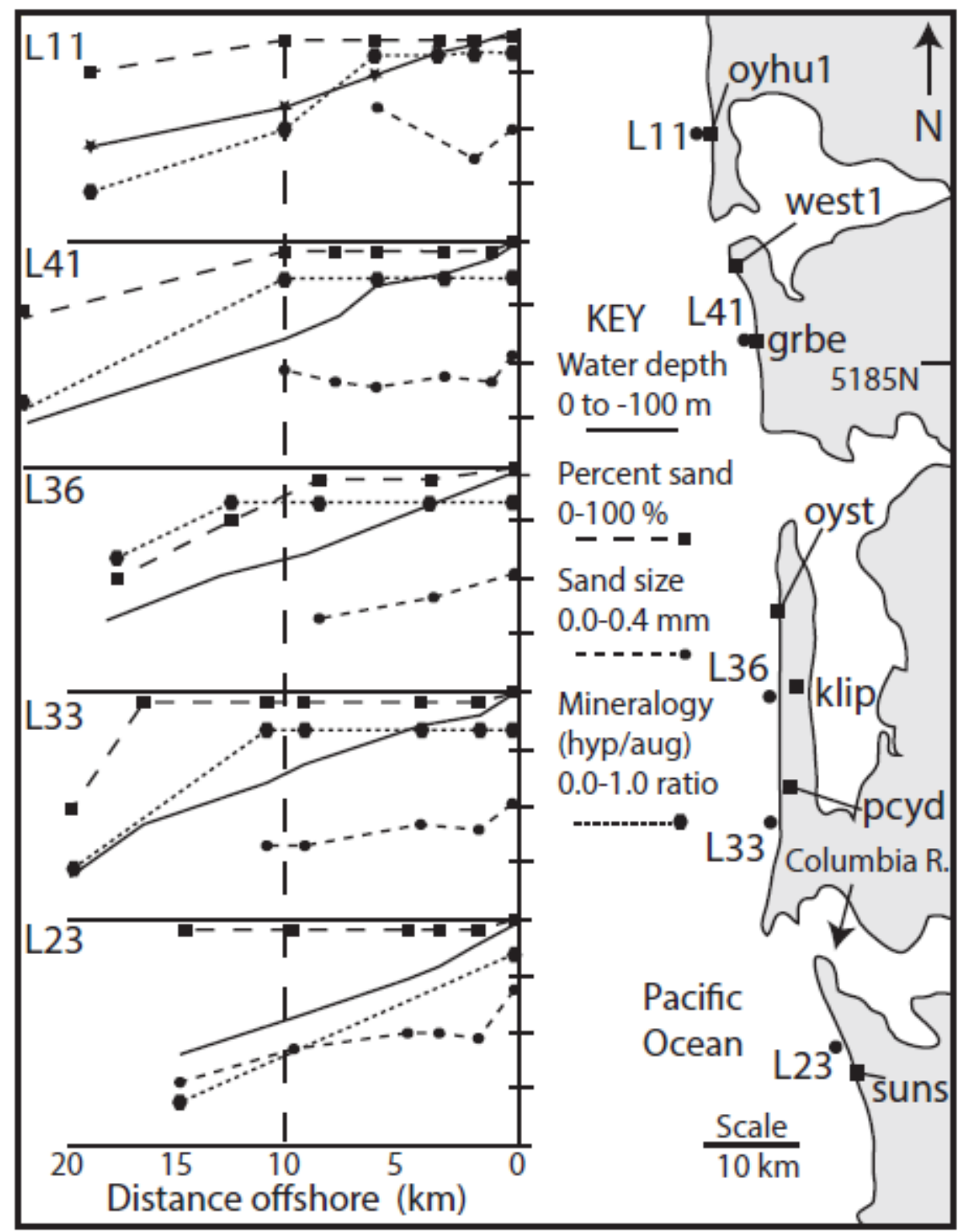

Figure 5 


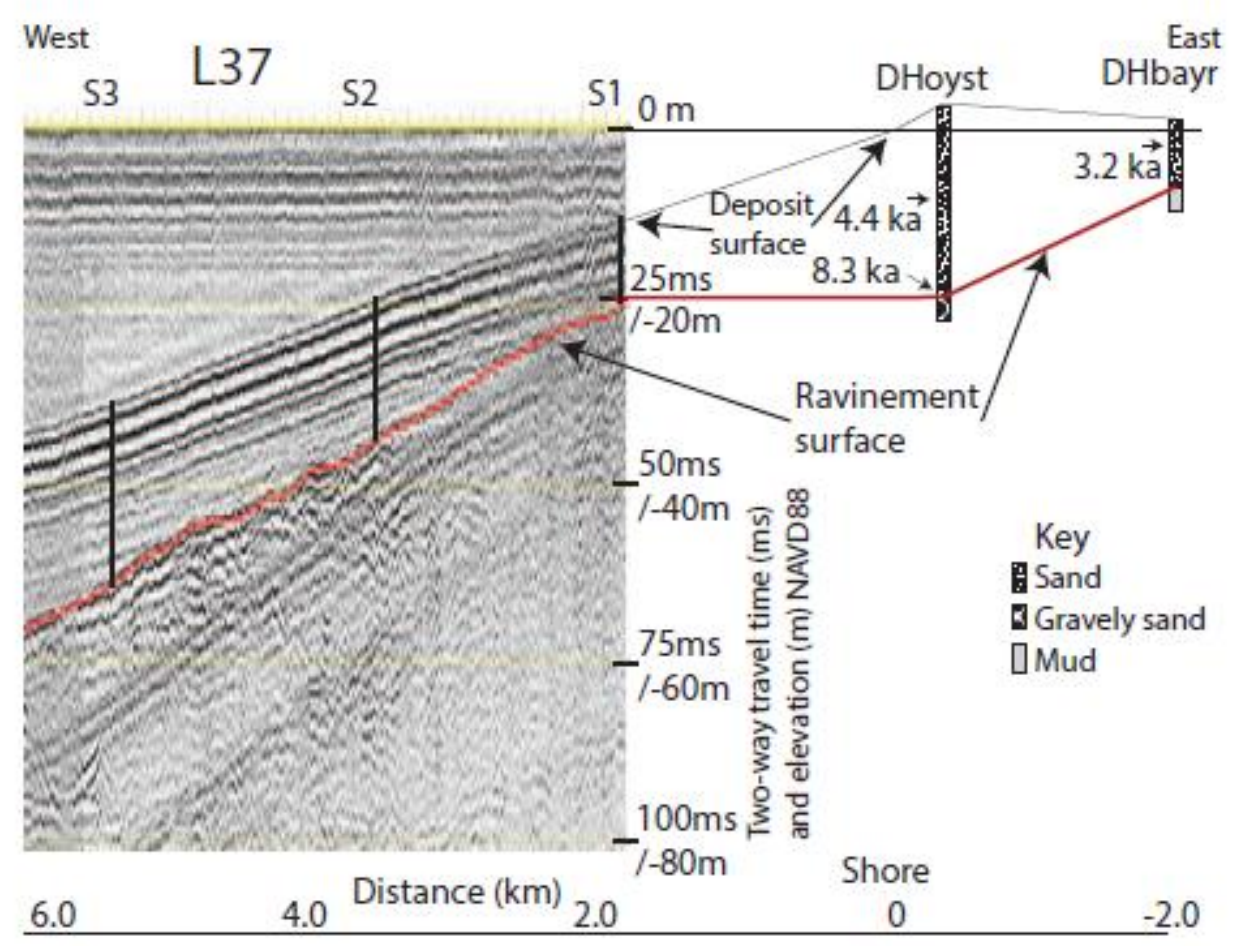

Figure 6 

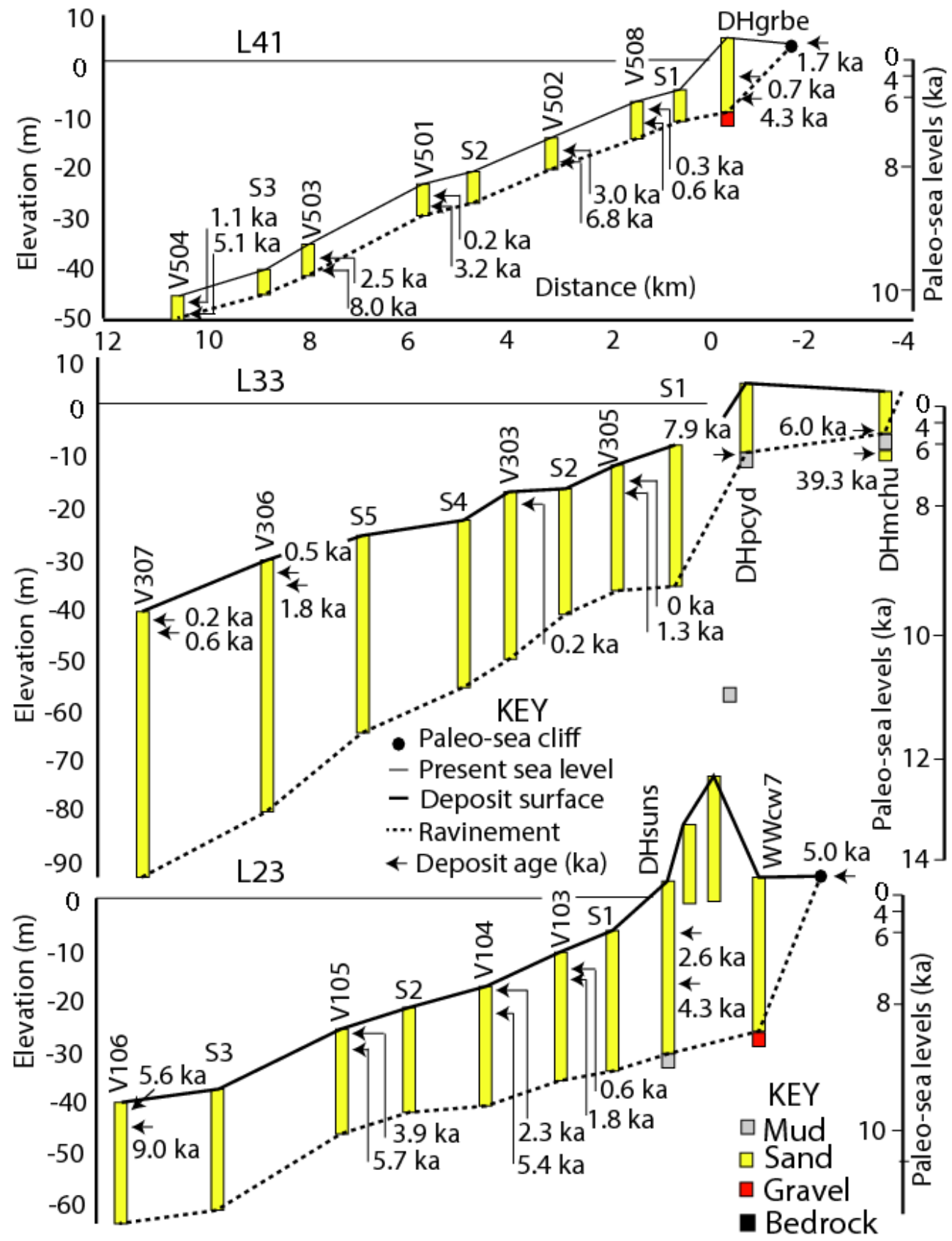

Figure 7 


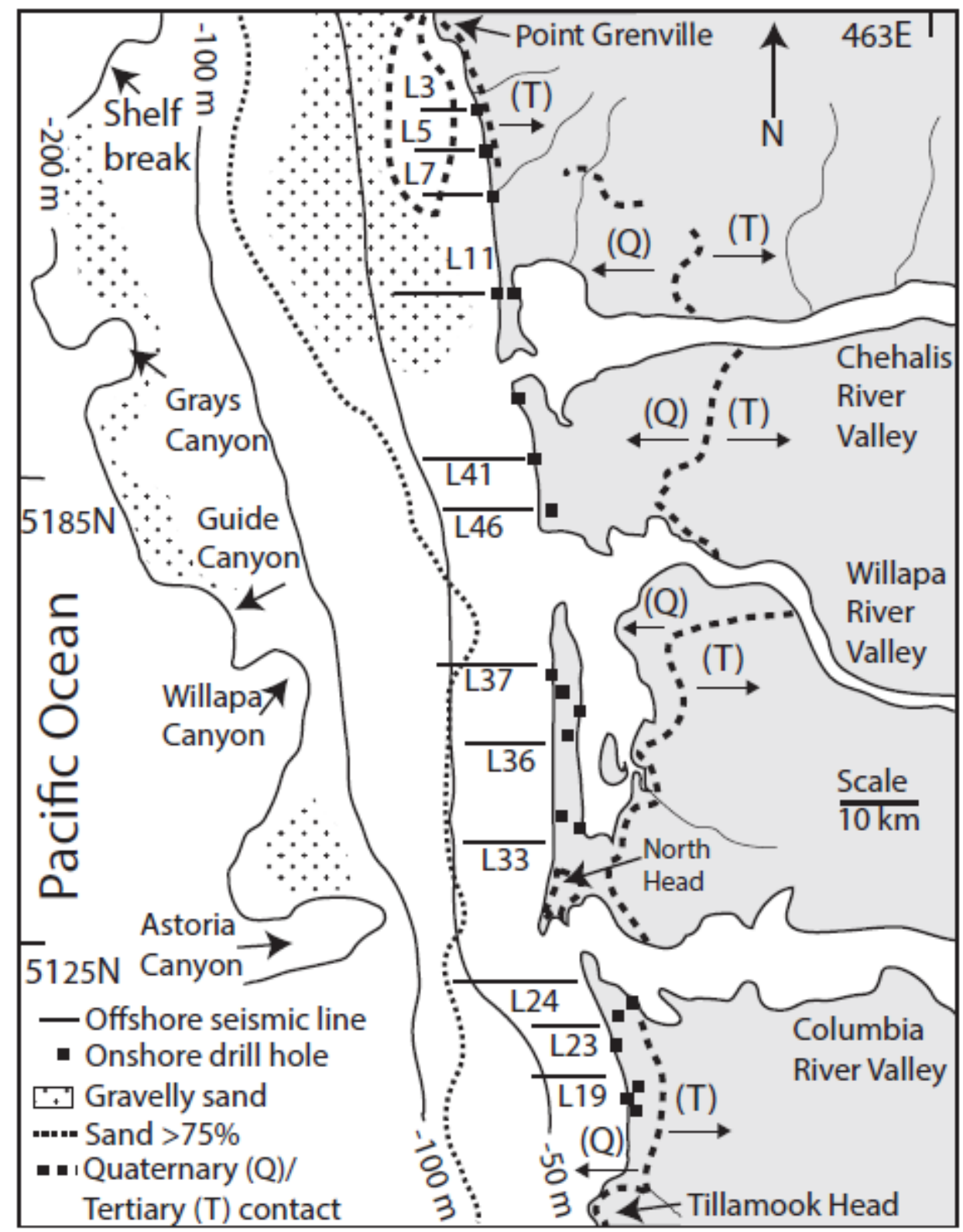

Figure 8 


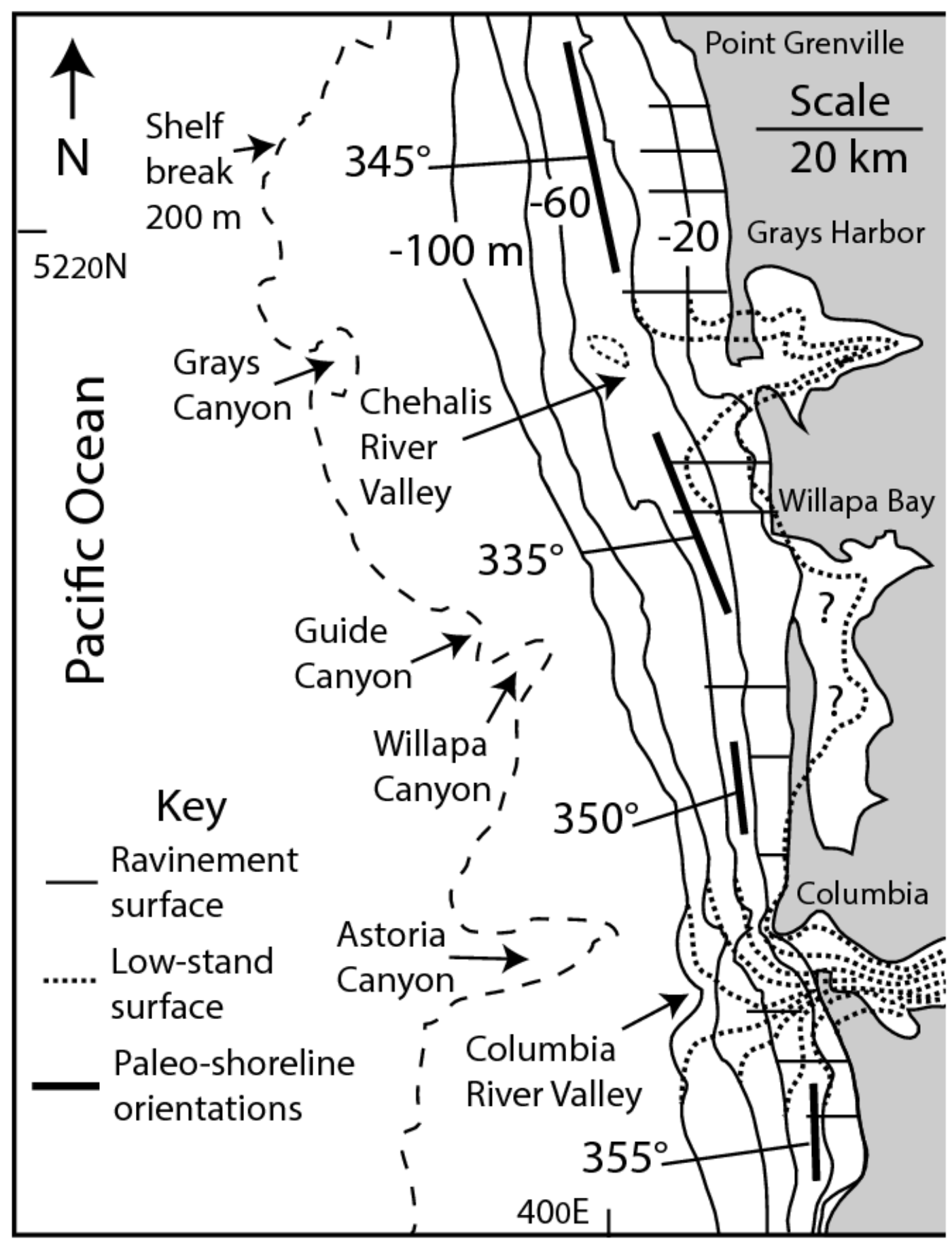

Figure 9 

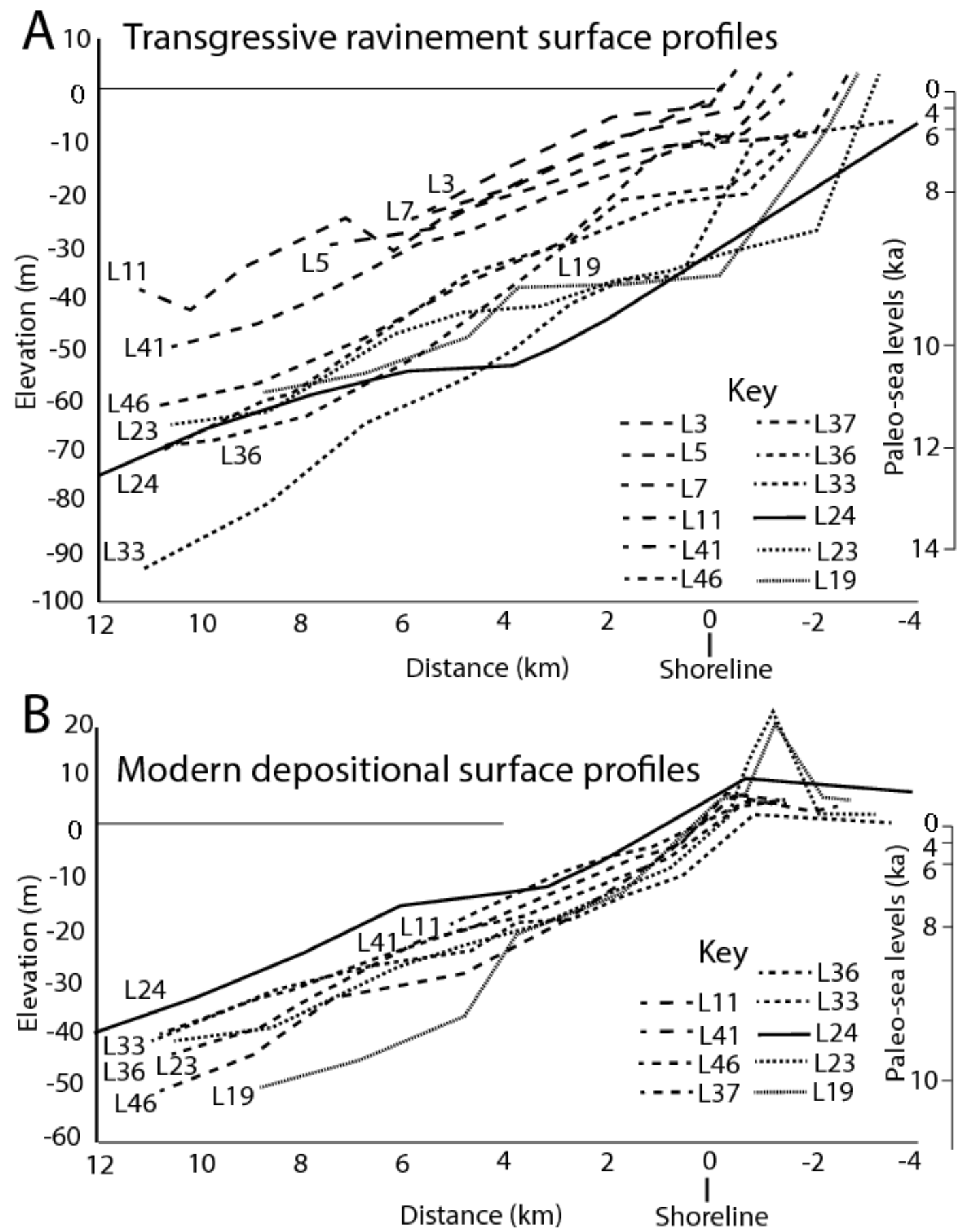

Figure 10 

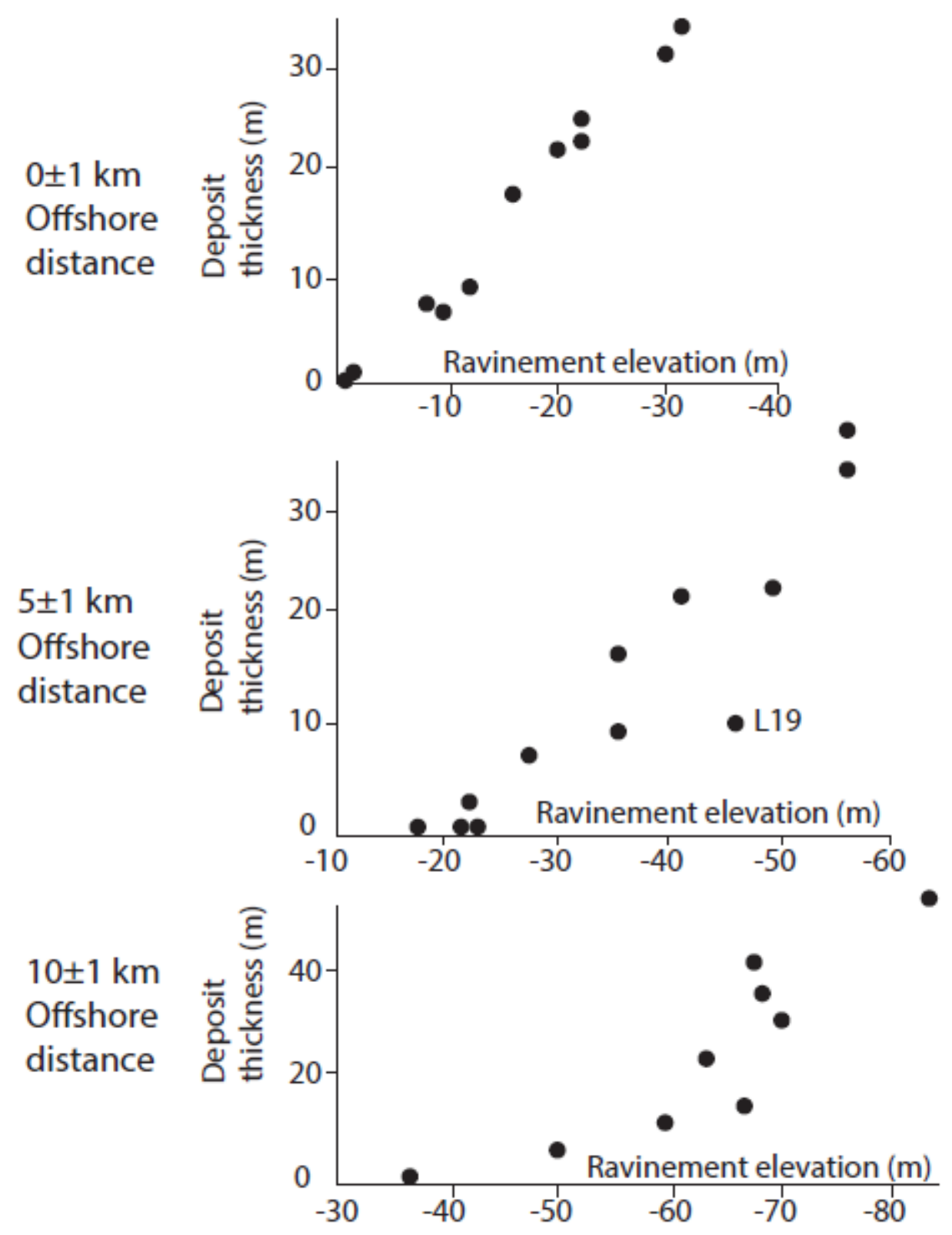

Figure 11 


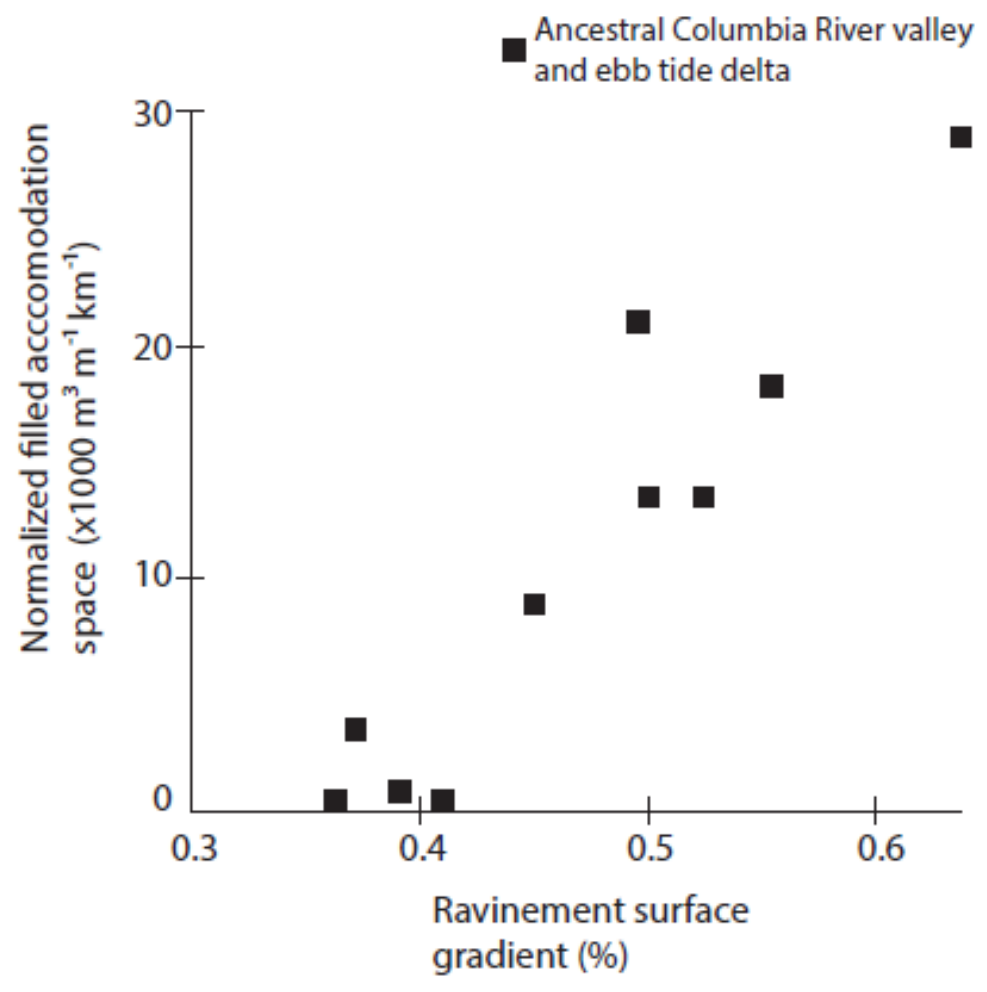

Figure 12

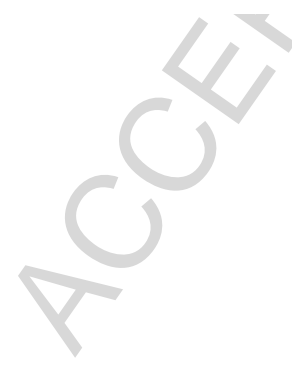




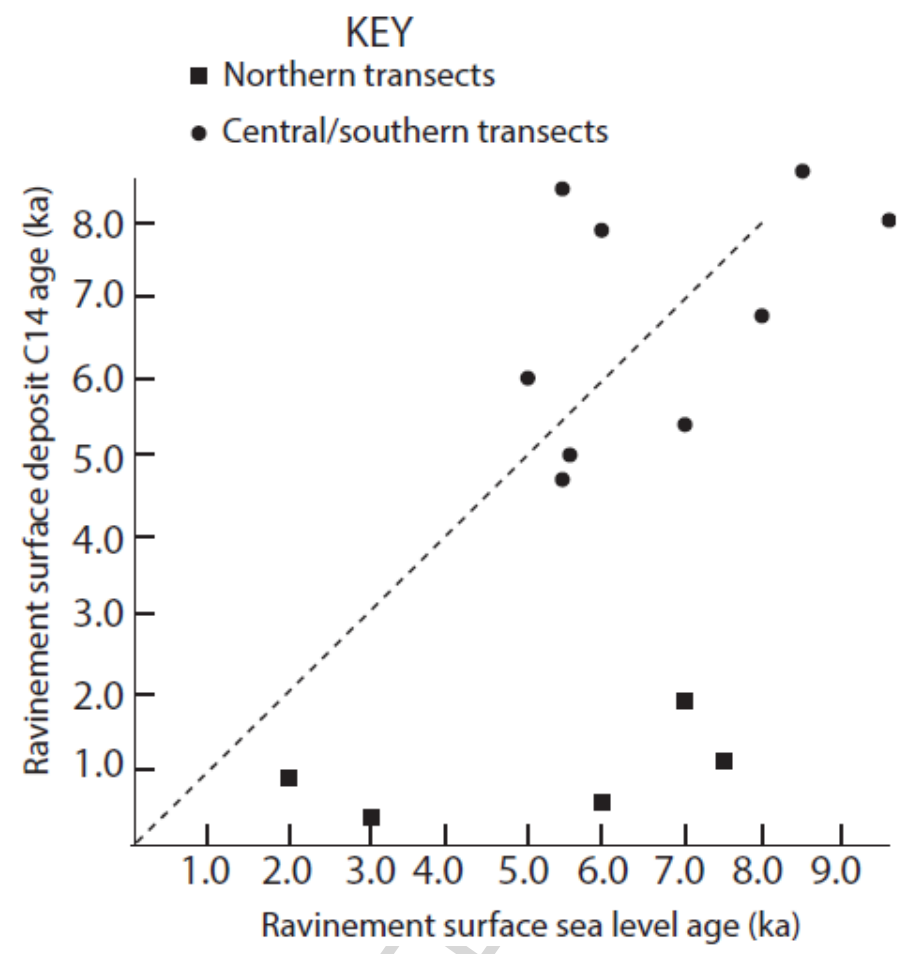

Figure 13 


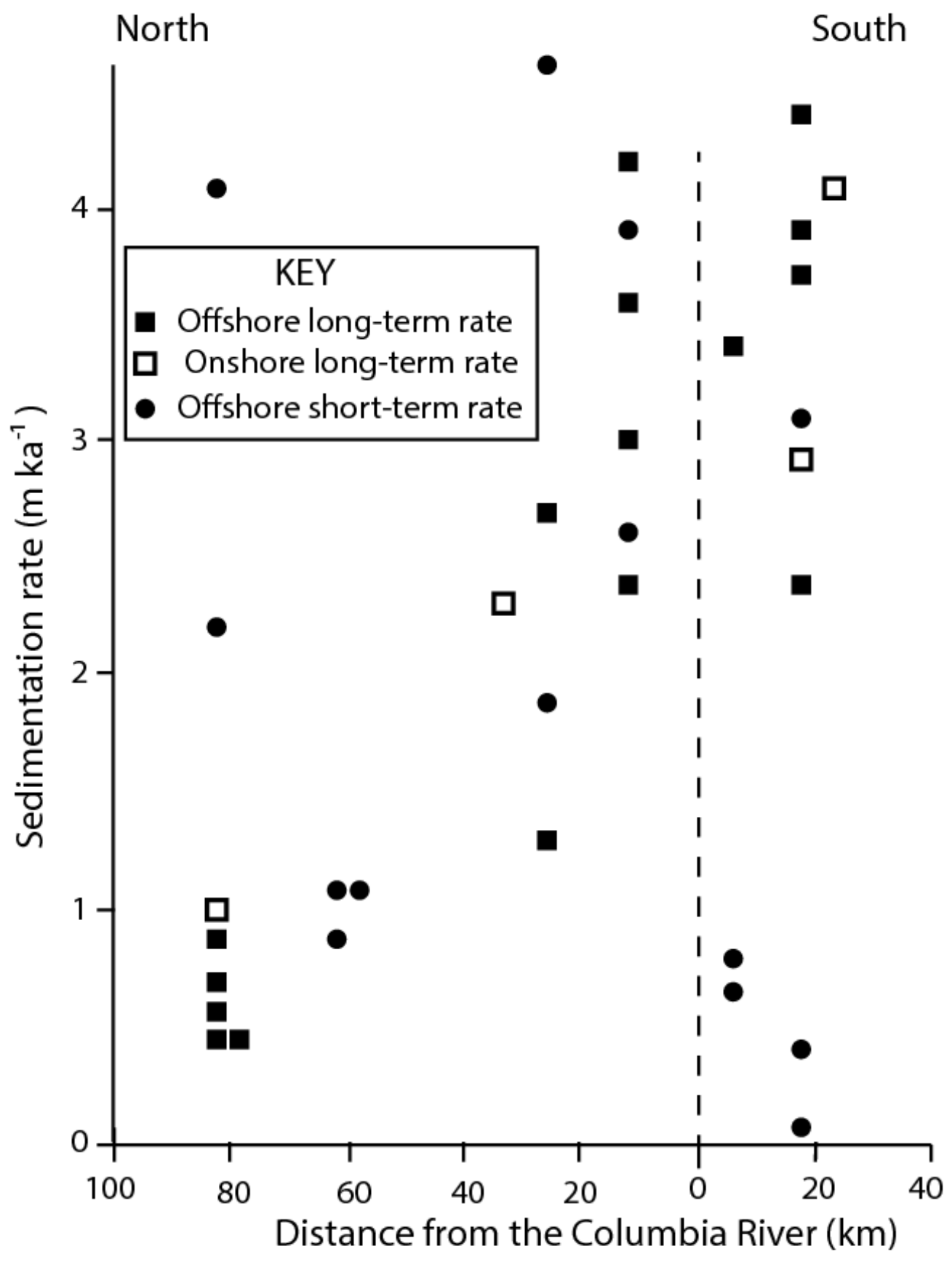

Figure 14 
PI

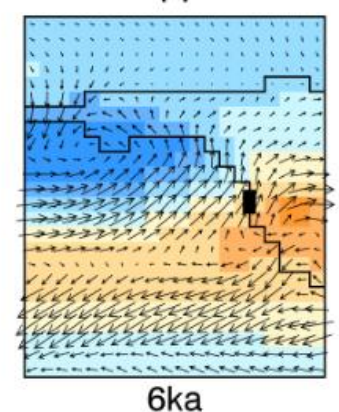

6ka

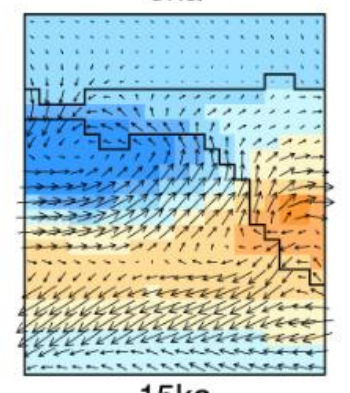

15ka
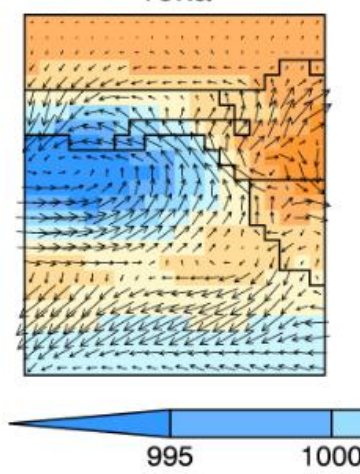

9ka

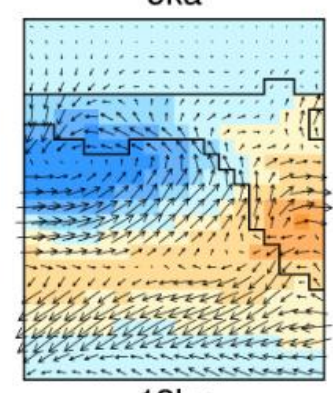

$18 \mathrm{ka}$

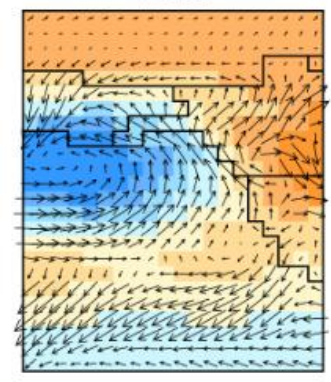

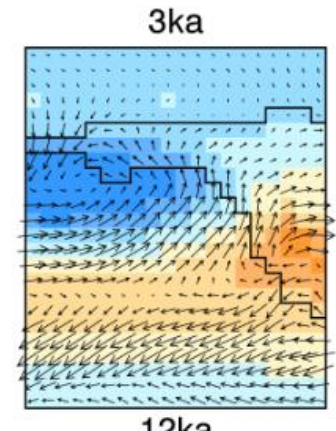

12ka

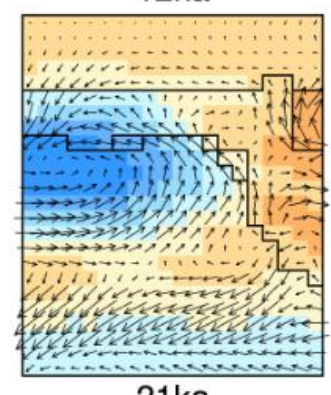

$21 \mathrm{ka}$

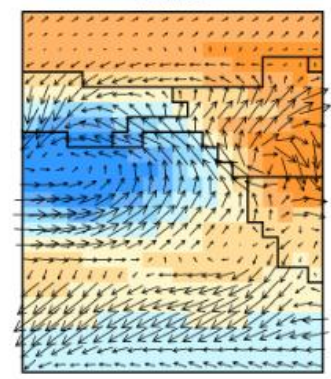

Figure 15 


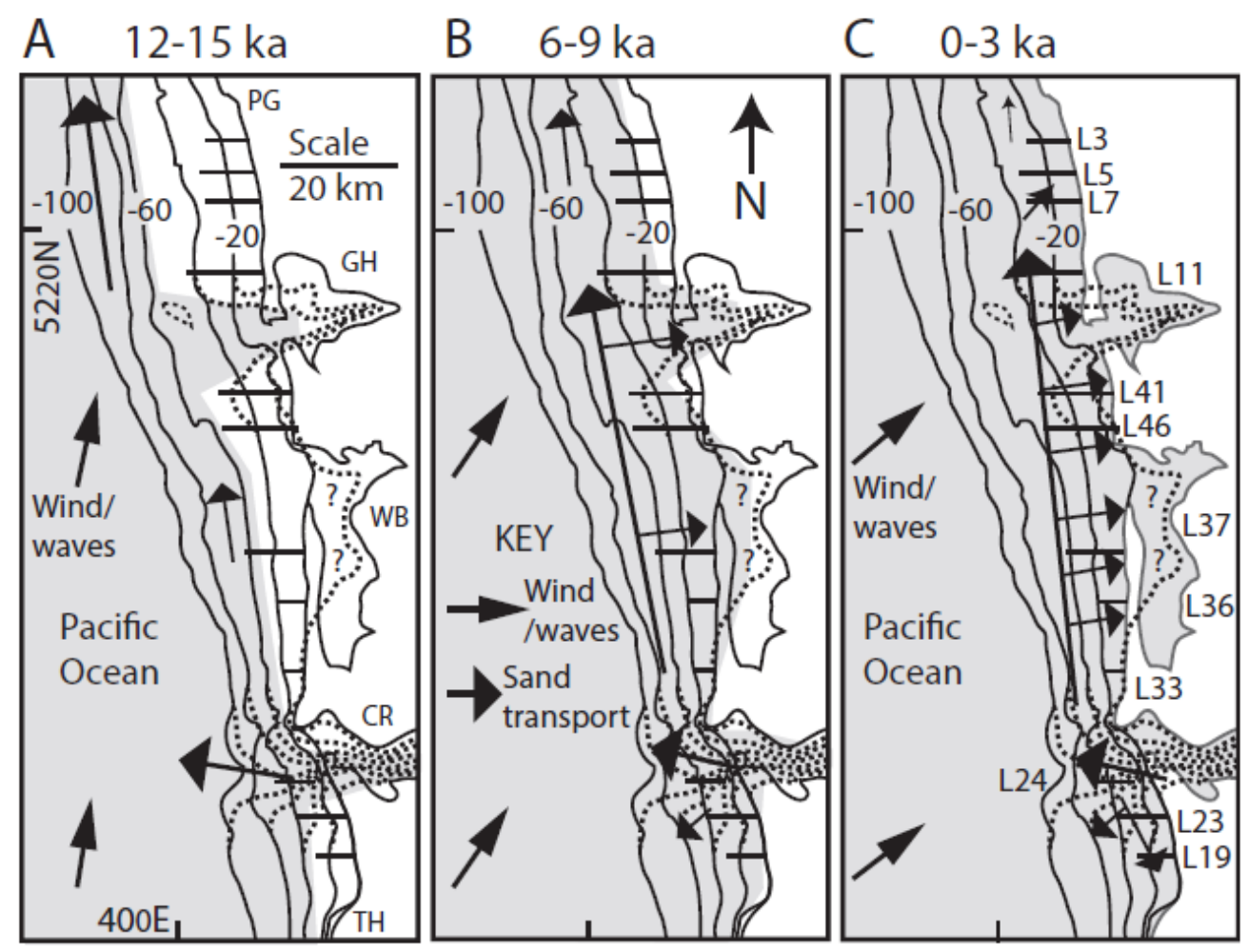

Figure 16 

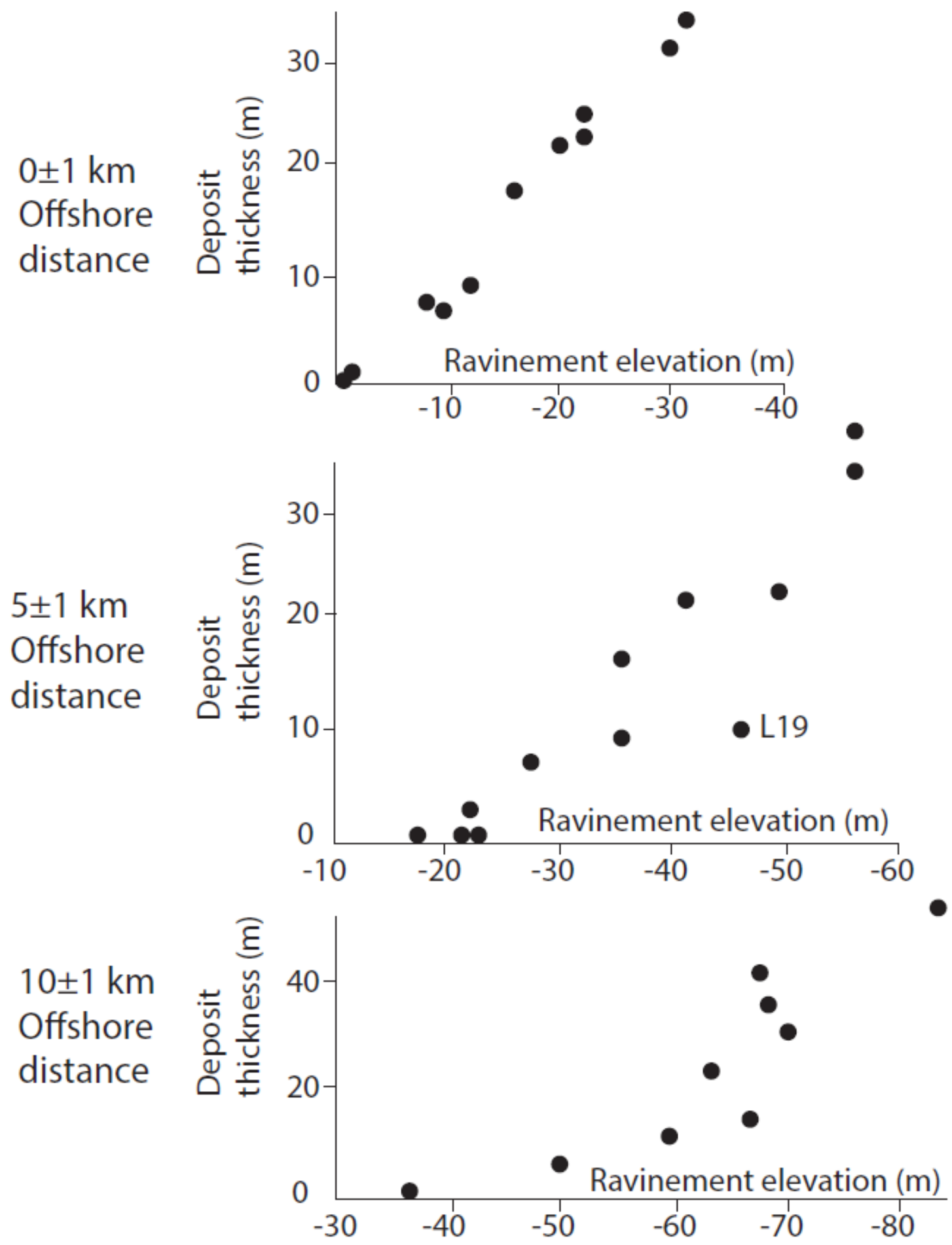

Figure 17 


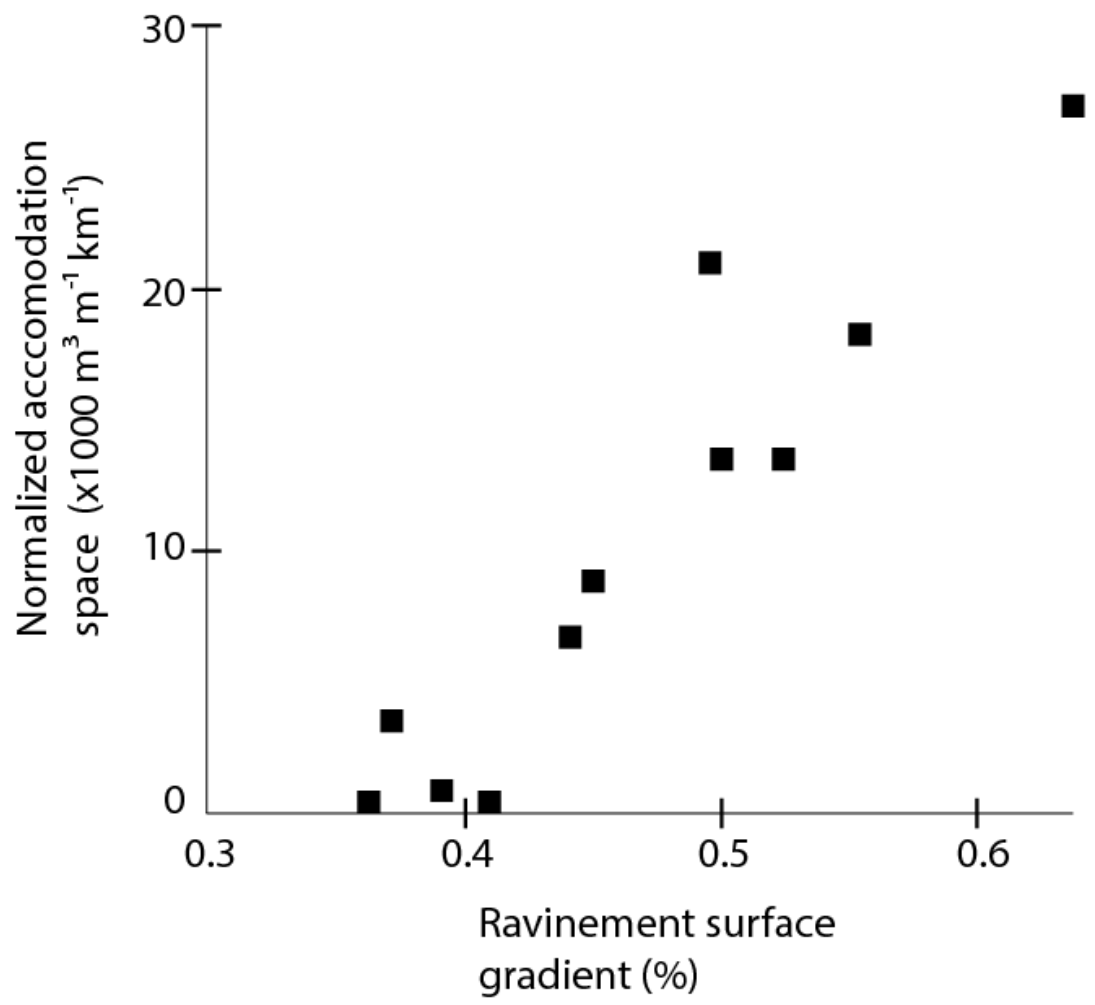

Figure 18 


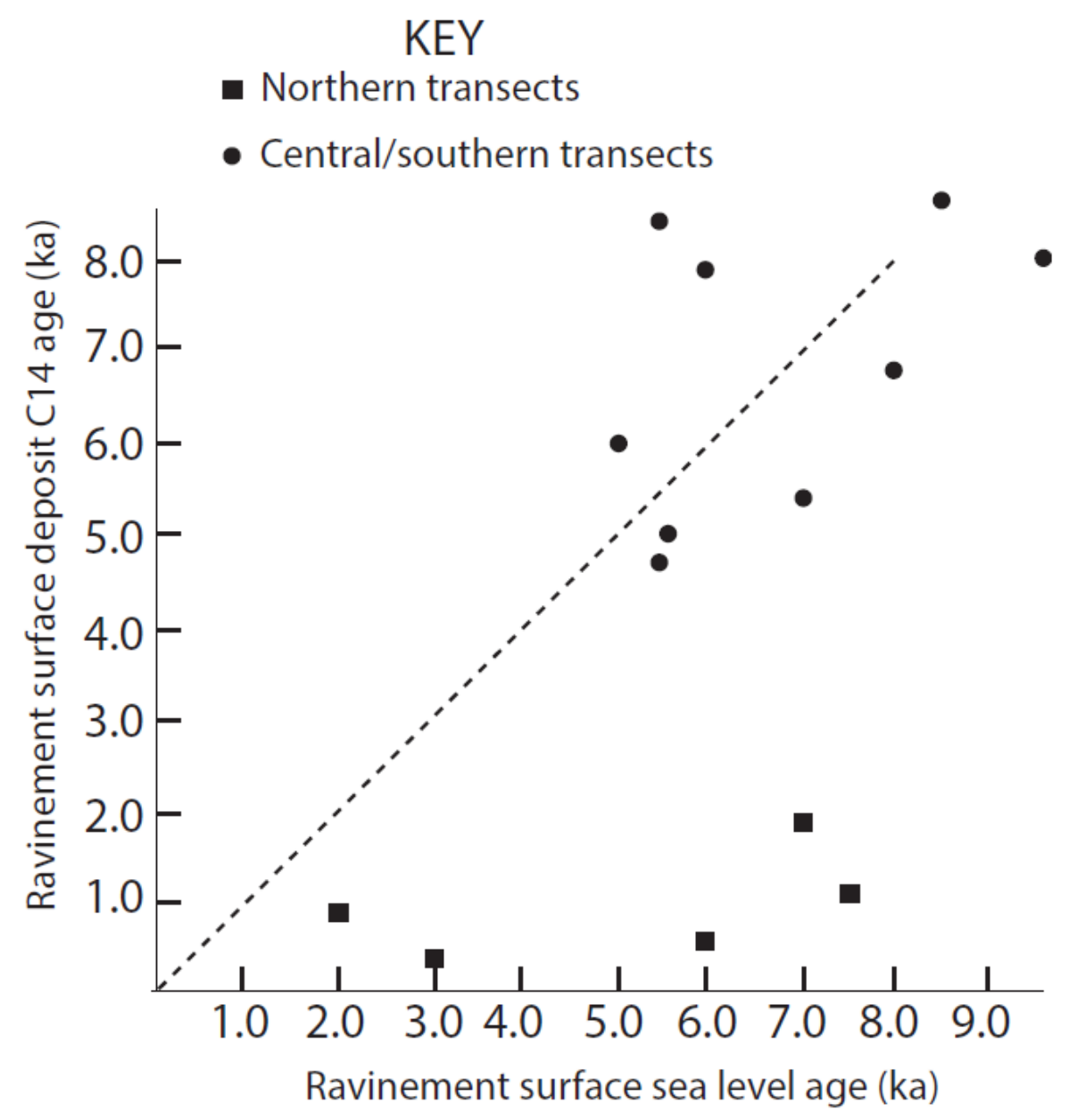

Figure 19 


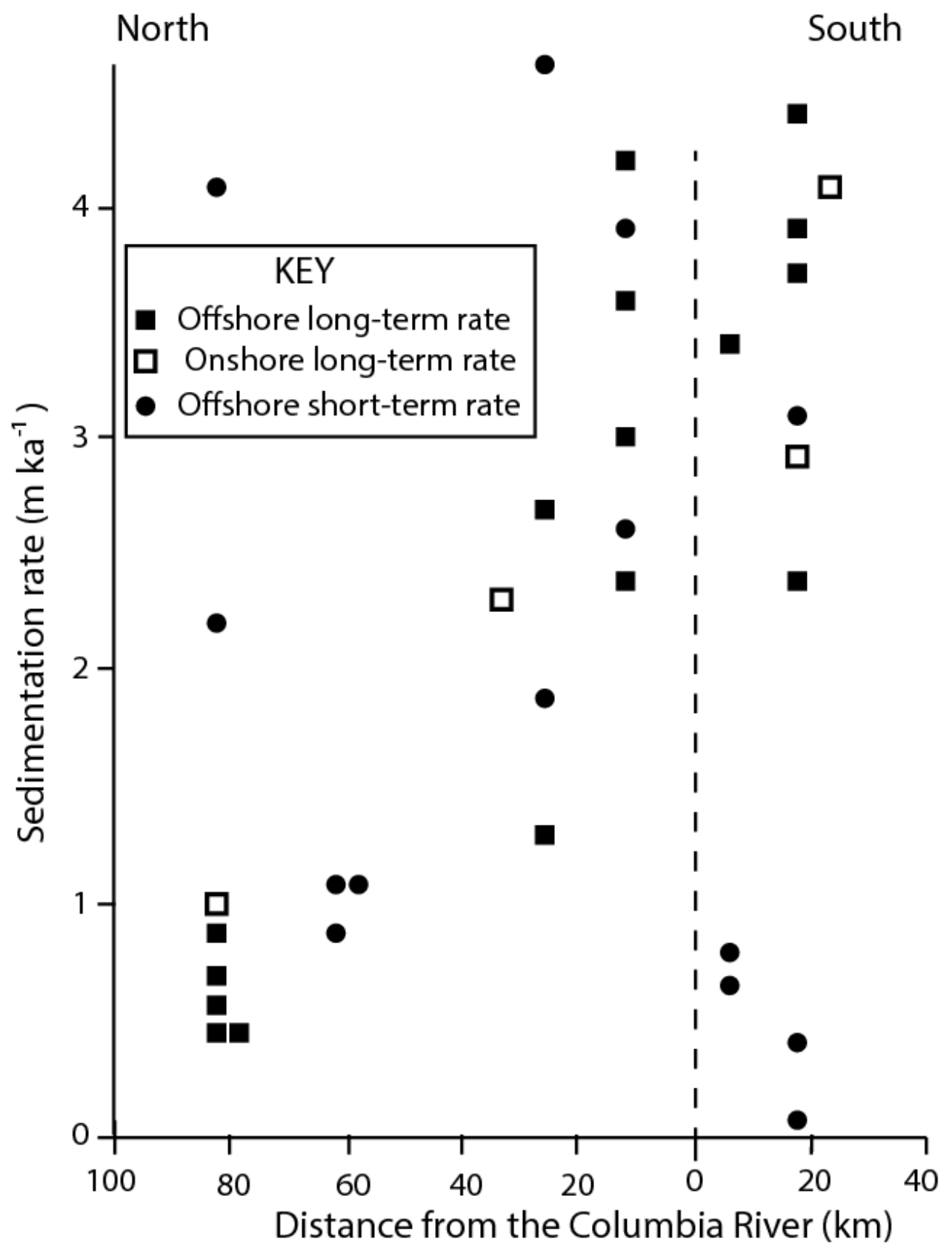

Figure 20 

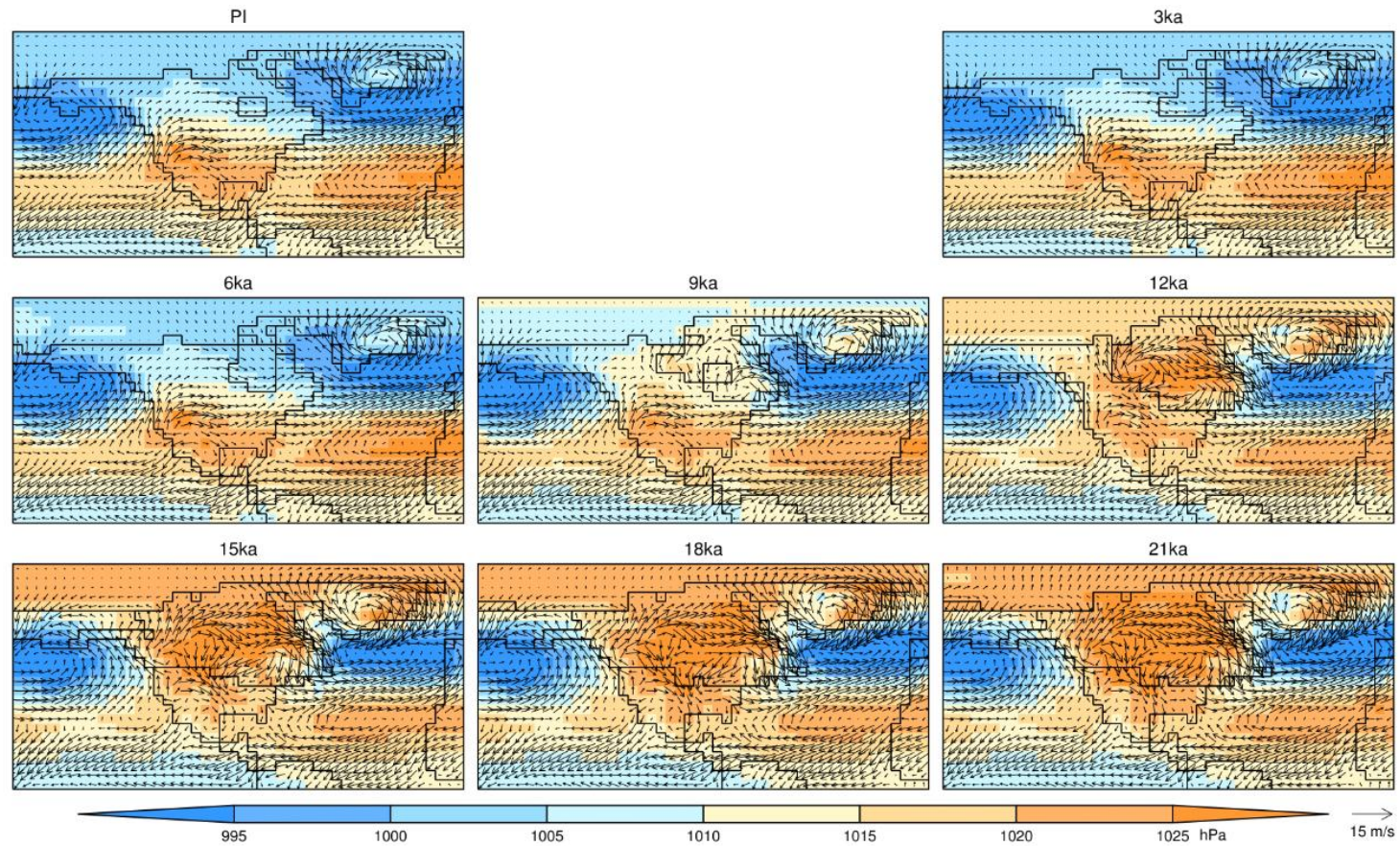

$1025 \mathrm{hPa}$

Figure 21 


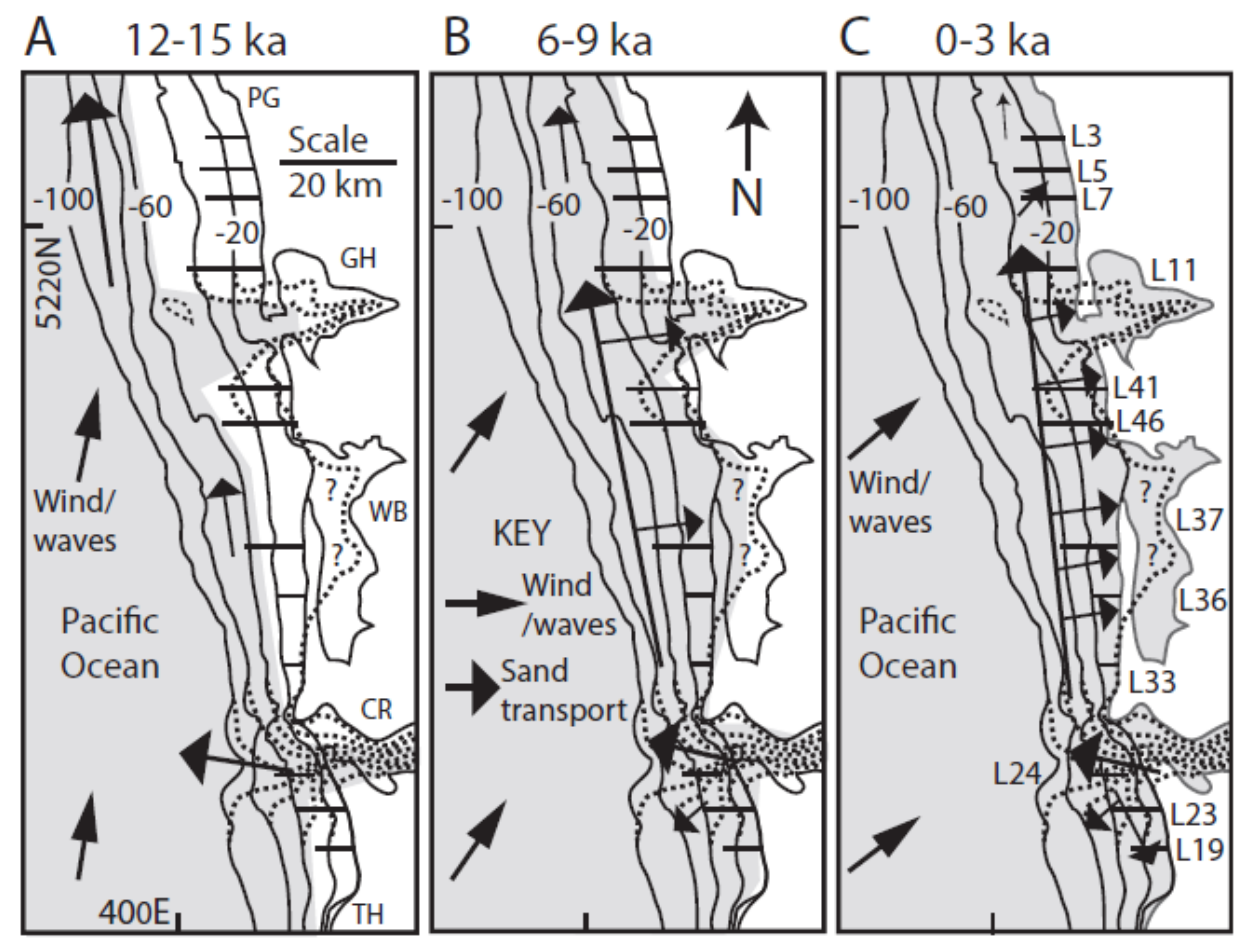

Figure 22 
Table 1. Post-ravinement accommodation spaces filled in the offshore inner-shelf transects.

\begin{tabular}{llllll}
\hline Transect & $\begin{array}{l}\text { Distance } \\
(\mathrm{m})\end{array}$ & $\begin{array}{l}\text { Ravinement } \\
\text { surface } \\
\text { gradient } \\
(\%)\end{array}$ & $\begin{array}{l}\text { Mean } \\
\text { deposit } \\
\text { thickness } \\
(\mathrm{m})\end{array}$ & $\begin{array}{l}\text { Deposit } \\
\text { cross-section } \\
\left(\mathrm{x} 1000 \mathrm{~m}^{2}\right)\end{array}$ & $\begin{array}{l}\text { Normalized } \\
\text { filled } \\
\text { accommodation } \\
\text { space } \\
\left(\mathrm{m}^{3} \mathrm{~m}^{-1} \mathrm{~km}^{-1}\right)\end{array}$ \\
\hline L3 & 5700 & 0.41 & 0 & 0 & 0 \\
L5 & 7500 & 0.36 & 0 & 0 & 0 \\
L7 & 6400 & 0.39 & 0.4 & 2.5 & 390 \\
L11 & 11900 & 0.37 & 3.4 & 40.5 & 3400 \\
L41 & 11400 & 0.44 & 6.8 & 77.5 & 6800 \\
L46 & 13200 & 0.45 & 8.7 & 114.8 & 8700 \\
L37 & 12700 & 0.53 & 13.9 & 176.5 & 13900 \\
L36 & 12800 & 0.55 & 18.4 & 235.5 & 18400 \\
L33 & 14800 & 0.63 & 27.2 & 402.5 & 29900 \\
L24 & 16200 & 0.44 & 33.0 & 534.6 & 33000 \\
L23 & 12800 & 0.50 & 21.4 & 273.9 & 21400 \\
L19 & 11300 & 0.50 & 13.8 & 155.9 & 13800 \\
\hline
\end{tabular}

Notes: Distance is east-to- west length (m) of the measured transect. Gradient is slope (\%) of the ravinement surface over the measured distance of the crosssetions. Mean deposit thickness is the average thickness of post-ravinement innershelf deposits (below $0 \mathrm{~m}$ NAVD88) in the onshore drill holes (DH) and offshore vibracore (V) and seismic profile (S) sites (Supplmental Figures 3-7). The L24 crosssection is extended to L24-S4 at $10.1 \mathrm{~km}$ distance from the present shoreline. Neither the ebb tide delta nor the tidal inlet are included in the L24 cross-section, likely canceling out their localized impacts on filled accommodation space at the mouth of the Columbia River. Deposit thickness data are from Supplemental Table 4. Post-ravinement deposit cross-section area $\left(\mathrm{x} 1000 \mathrm{~m}^{2}\right)$ is taken from the mean deposit thickness multiplied by transect length. Normalized accommodation space $\left(\mathrm{m}^{3} \mathrm{~m}^{-1} \mathrm{~km}^{-1}\right)$ is taken from the mean deposit thickness in each transect multiplied by 1.0 meter width (alongshore) and 1.0 kilometer distance (across-shelf) along the transect. 
Table 2: Long-term (0.3-13 ka) sedimentation rates in the CRLC inner-shelf.

\begin{tabular}{lllll}
\hline Line/site & $\begin{array}{l}\text { Section midpoint } \\
\text { and range of } \\
\text { elevations }(\mathrm{m})\end{array}$ & $\begin{array}{l}\text { Section midpoint } \\
\text { and range of } \\
\text { ages }(\mathrm{ka})\end{array}$ & $\begin{array}{l}\text { Section sedi- } \\
\text { mentation rate } \\
\left(\mathrm{m} \mathrm{ka}^{-1}\right)\end{array}$ & $\begin{array}{l}\text { Sea level } \\
\text { rise rate } \\
\left(\mathrm{m} \mathrm{ka}^{-1}\right)\end{array}$ \\
\hline L41DHgreb1 & $-6.6 \pm 2.3$ & $4.3 \pm 2.3$ & 1.0 & 2 \\
L41V508 & $-12.5 \pm-3.1$ & $3.9 \pm 3.6$ & 0.9 & 4.7 \\
L41V502 & $-19.1 \pm 1.9$ & $5.5 \pm 2.5$ & 0.7 & 12.3 \\
L41V501 & $-28.0 \pm 1.7$ & $4.6 \pm 4.4$ & 0.4 & 6.6 \\
L41503 & $-39.4 \pm 1.5$ & $6 \pm-3.5$ & 0.4 & 15.5 \\
L41V504 & $-47.4 \pm 2.6$ & $5.6 \pm 4.5$ & 0.6 & 17.3 \\
L37DHoyst & $-11.8 \pm 4.7$ & $6.5 \pm 2.1$ & 2.3 & 3.1 \\
L36V302 & $-26.0 \pm 5.1$ & $5.0 \pm 4.0$ & 1.3 & 11.2 \\
L36V301 & $-46.6 \pm 12.1$ & $6.4 \pm 4.5$ & 2.7 & 14.2 \\
L33V305 & $-26.1 \pm 9.8$ & $5.4 \pm 4.1$ & 2.4 & 9.3 \\
L33V303 & $-34.6 \pm 14.9$ & $5.1 \pm 4.9$ & 3.0 & 14.9 \\
L33V306 & $-57.5 \pm 22.3$ & $7.1 \pm 5.3$ & 4.2 & 13.5 \\
L33V307 & $-68.4 \pm 24.1$ & $7.3 \pm 6.7$ & 3.6 & 11.5 \\
L24V903 & $-66.7 \pm 15.3$ & $8.6 \pm 4.5$ & 3.4 & 10.5 \\
L23DHsuns & $-23.3 \pm 6.7$ & $6.7 \pm 2.3$ & 2.9 & 13.4 \\
L23V103 & $-24.4 \pm 9.2$ & $5.7 \pm 3.9$ & 2.4 & 8.7 \\
L23V104 & $-30.8 \pm 9.1$ & $7.5 \pm 2.1$ & 4.4 & 13.9 \\
L23V105 & $-36.3 \pm 7.0$ & $7.6 \pm 1.9$ & 3.7 & 28 \\
L23V106 & $-51.8 \pm 11.5$ & $8.5 \pm 2.9$ & 3.9 & 11.5 \\
L19Dhdelr & $-19.6 \pm 13.3$ & $5.8 \pm 3.3$ & 4.1 & 7.2 \\
\hline
\end{tabular}

Notes: Section elevation intervals ( $\mathrm{m}$ ) and corresponding section ages (ka) of lower ravinement surfaces and overlying deposits are used to calculate section sedimentation rates $\left(\mathrm{m} \mathrm{ka}^{-1}\right)$. Elevations and ages of lower bounding ravinement surfaces and overlying deposit $\mathrm{C}^{14}$ samples are from Table 4 . Rates of sea level rise $\left(\mathrm{m} \mathrm{ka}{ }^{-1}\right)$ that correspond to the dated sections are estimated from the CRLC sea level curve shown in Figure 2 Part C. 
Table 3: Short-term (0-3.8 ka) sedimentation rates in the CRLC inner-shelf.

\begin{tabular}{llll}
\hline Line/site & $\begin{array}{l}\text { Section midpoint } \\
\text { and range of } \\
\text { elevations (m) }\end{array}$ & $\begin{array}{l}\text { Section midpoint } \\
\text { and range of } \\
\text { ages (ka) }\end{array}$ & $\begin{array}{l}\text { Section sedi- } \\
\text { mentation rate } \\
\left(\mathrm{m} \mathrm{ka}^{-1}\right)\end{array}$ \\
\hline L11V707 & $-9.9+/-2.1$ & $0.9+/-0.9$ & 2.3 \\
L11V701 & $-14.0+/-2.3$ & $0.5+/-0.5$ & 4.1 \\
L41V502 & $-15.9+/-1.4$ & $1.5+/-1.5$ & 0.9 \\
L41V503 & $-36.5+/-1.5$ & $1.3+/-1.3$ & 1.1 \\
L41V504 & $-44.2+/-0.6$ & $0.5+/-0.5$ & 1.1 \\
L36V302 & $-18.6+/-2.3$ & $0.5+/-0.5$ & 4.6 \\
L36V301 & $-32.7+/-1.9$ & $0.9+/-0.9$ & 1.9 \\
L33V305 & $-13.7+/-2.5$ & $0.7+/-0.7$ & 3.9 \\
L33V306 & $-32.7+/-2.3$ & $0.9+/-0.9$ & 2.6 \\
L24V102 & $-14.1+/-0.5$ & $1.5+/-1.5$ & 0.7 \\
L24V903 & $-49.1+/-0.7$ & $0.8+/-0.8$ & 0.8 \\
L23V103 & $-12.5+/-2.7$ & $0.9+/-0.9$ & 3.1 \\
L23V104 & $-16.8+/-0.5$ & $1.1+/-1.1$ & 0.4 \\
L23V105* & $-24.7+/-0.1$ & $1.9+-1.9$ & 0.1 \\
\hline
\end{tabular}

Notes: Section elevation intervals (m) and corresponding section ages (ka) of radiocarbon deposits and modern surfaces are used to calculate recent short-term sedimentation rates $\left(\mathrm{m} \mathrm{ka}^{-1}\right)$. Elevations and ages of the deposit $\mathrm{C}^{14}$ samples, ravinement surfaces and modern surfaces are from Supplemental Table 4. 
Table 4: Post-ravinement sediment volumes for the CRLC inner-shelf transect segments.

\begin{tabular}{llll}
\hline Transect & $\begin{array}{l}\text { Along-shelf } \\
\text { segment }(\mathrm{m})\end{array}$ & $\begin{array}{l}\text { Cross-section } \\
\text { area }\left(\mathrm{m}^{2}\right)\end{array}$ & $\begin{array}{l}\text { Shelf segment } \\
\text { volume }\left(\mathrm{x} 10^{6} \mathrm{~m}^{3}\right)\end{array}$ \\
\hline L7 & 8080 & 2500 & 20 \\
L11 & 16570 & 40500 & 671 \\
L41 & 15330 & 77500 & 1188 \\
L46 & 14930 & 114800 & 1714 \\
L37 & 16430 & 176500 & 2900 \\
L36 & 10550 & 235500 & 2485 \\
L33 & 13900 & 402500 & 5595 \\
L24 & 11600 & 534600 & 6201 \\
L23 & 8960 & 273900 & 2454 \\
L19 & 10110 & 155900 & 1576 \\
\hline
\end{tabular}

Notes: Along-shelf segment lengths (m) for each across-shelf transect were calculated from mid-points between 1) transects, 2) the south bounding Tillamook Headland, and 3) the northern bound of shelf sand accumulation between transects L7 and L5. Transect cross-section areas are taken from Table 1. Shelf segment volumes $\left(\mathrm{x}^{1} 0^{6} \mathrm{~m}^{3}\right)$ are derived from the products of along-shelf segment length and corresponding transect cross-section areas. 
Table 5. Post-ravinement accommodation spaces filled in the offshore inner-shelf transects.

\begin{tabular}{llllll}
\hline Transect & $\begin{array}{l}\text { Distance } \\
(\mathrm{m})\end{array}$ & $\begin{array}{l}\text { Ravinement } \\
\text { surface } \\
\text { gradient } \\
(\%)\end{array}$ & $\begin{array}{l}\text { Mean } \\
\text { deposit } \\
\text { thickness } \\
(\mathrm{m})\end{array}$ & $\begin{array}{l}\text { Deposit } \\
\text { cross-section } \\
\left(\mathrm{x} 1000 \mathrm{~m}^{2}\right)\end{array}$ & $\begin{array}{l}\text { Normalized } \\
\text { accommodation } \\
\text { space } \\
\left(\mathrm{m}^{3} \mathrm{~m}^{-1} \mathrm{~km}^{-1}\right)\end{array}$ \\
\hline L3 & 5700 & 0.41 & 0 & 0 & 0 \\
L5 & 7500 & 0.36 & 0 & 0 & 0 \\
L7 & 6400 & 0.39 & 0.4 & 2.5 & 390 \\
L11 & 11900 & 0.37 & 3.4 & 40.5 & 3400 \\
L41 & 11400 & 0.44 & 6.8 & 77.5 & 6800 \\
L46 & 13200 & 0.45 & 8.7 & 114.8 & 8700 \\
L37 & 12700 & 0.53 & 13.9 & 176.5 & 13900 \\
L36 & 12800 & 0.55 & 18.4 & 235.5 & 18400 \\
L33 & 14800 & 0.63 & 27.2 & 402.5 & 29900 \\
L24 & 16200 & 0.44 & 33.0 & 534.6 & 33000 \\
L23 & 12800 & 0.50 & 21.4 & 273.9 & 21400 \\
L19 & 11300 & 0.50 & 13.8 & 155.9 & 13800 \\
\hline
\end{tabular}

Notes: Distance is east-to- west length $(\mathrm{m})$ of the measured transect. Gradient is slope (\%) of the ravinement surface over the measured distance. Mean deposit thickness is the average thickness of post-ravinement inner-shelf deposits (below 0 $m$ NAVD88) in the onshore drill holes (DH) and offshore vibracore (V) and seismic profile (S) sites (Figures 9-13). The L24 cross-section is extended to L24-S4 at 10.1 $\mathrm{km}$ distance from the present shoreline. Neither the ebb tide delta nor the tidal inlet are included in the L24 cross-section, likely canceling out their localized impacts on filled accommodation space at the mouth of the Columbia River. Deposit thickness data are from Table 4. Post-ravinement deposit cross-section area $\left(\mathrm{x} 1000 \mathrm{~m}^{2}\right)$ is taken from the mean deposit thickness multiplied by transect length. Normalized accommodation space $\left(\mathrm{m}^{3} \mathrm{~m}^{-1} \mathrm{~km}^{-1}\right)$ is taken from the mean deposit thickness in each transect multiplied by 1.0 meter width (alongshore) and 1.0 kilometer distance (across-shelf) along the transect. 
Table 6: Long-term sedimentation rates in the CRLC inner-shelf.

\begin{tabular}{lllll}
\hline Line/site & $\begin{array}{l}\text { Section midpoint } \\
\text { and range of } \\
\text { elevations (m) }\end{array}$ & $\begin{array}{l}\text { Section midpoint } \\
\text { and range of } \\
\text { ages (ka) }\end{array}$ & $\begin{array}{l}\text { Section sedi- } \\
\text { mentation rate } \\
\left(\mathrm{m} \mathrm{ka}^{-1}\right)\end{array}$ & $\begin{array}{l}\text { Sea level } \\
\text { rise rate } \\
\left(\mathrm{m} \mathrm{ka}^{-1}\right)\end{array}$ \\
\hline L41DHgreb1 & $-6.6 \pm 2.3$ & $4.3 \pm 2.3$ & 1.0 & 2 \\
L41V508 & $-12.5 \pm-3.1$ & $3.9 \pm 3.6$ & 0.9 & 4.7 \\
L41V502 & $-19.1 \pm 1.9$ & $5.5 \pm 2.5$ & 0.7 & 12.3 \\
L41V501 & $-28.0 \pm 1.7$ & $4.6 \pm 4.4$ & 0.4 & 6.6 \\
L41503 & $-39.4 \pm 1.5$ & $6 \pm-3.5$ & 0.4 & 15.5 \\
L41V504 & $-47.4 \pm 2.6$ & $5.6 \pm 4.5$ & 0.6 & 17.3 \\
L37DHoyst & $-11.8 \pm 4.7$ & $6.5 \pm 2.1$ & 2.3 & 3.1 \\
L36V302 & $-26.0 \pm 5.1$ & $5.0 \pm 4.0$ & 1.3 & 11.2 \\
L36V301 & $-46.6 \pm 12.1$ & $6.4 \pm 4.5$ & 2.7 & 14.2 \\
L33V305 & $-26.1 \pm 9.8$ & $5.4 \pm 4.1$ & 2.4 & 9.3 \\
L33V303 & $-34.6 \pm 14.9$ & $5.1 \pm 4.9$ & 3.0 & 14.9 \\
L33V306 & $-57.5 \pm 22.3$ & $7.1 \pm 5.3$ & 4.2 & 13.5 \\
L33V307 & $-68.4 \pm 24.1$ & $7.3 \pm 6.7$ & 3.6 & 11.5 \\
L24V903 & $-66.7 \pm 15.3$ & $8.6 \pm 4.5$ & 3.4 & 10.5 \\
L23DHsuns & $-23.3 \pm 6.7$ & $6.7 \pm 2.3$ & 2.9 & 13.4 \\
L23V103 & $-24.4 \pm 9.2$ & $5.7 \pm 3.9$ & 2.4 & 8.7 \\
L23V104 & $-30.8 \pm 9.1$ & $7.5 \pm 2.1$ & 4.4 & 13.9 \\
L23V105 & $-36.3 \pm 7.0$ & $7.6 \pm 1.9$ & 3.7 & 28 \\
L23V106 & $-51.8 \pm 11.5$ & $8.5 \pm 2.9$ & 3.9 & 11.5 \\
L19Dhdelr & $-19.6 \pm 13.3$ & $5.8 \pm 3.3$ & 4.1 & 7.2 \\
\hline
\end{tabular}

Notes: Section elevation intervals (m) and corresponding section ages (ka) of lower ravinement surfaces and overlying deposits are used to calculate section sedimentation rates $\left(\mathrm{m} \mathrm{ka}^{-1}\right)$. Elevations and ages of lower bounding ravinement surfaces and overlying deposit $\mathrm{C}^{14}$ samples are from Table 4 . Rates of sea level rise $\left(\mathrm{m} \mathrm{ka}^{-1}\right)$ that correspond to the dated sections are estimated from the CRLC sea level curve shown in Figure 2 Part C. 
Table 7: Short-term sedimentation rates in the CRLC inner-shelf.

\begin{tabular}{llll}
\hline Line/site & $\begin{array}{l}\text { Section midpoint } \\
\text { and range of } \\
\text { elevations (m) }\end{array}$ & $\begin{array}{l}\text { Section midpoint } \\
\text { and range of } \\
\text { ages (ka) }\end{array}$ & $\begin{array}{l}\text { Section sedi- } \\
\text { mentation rate } \\
\left(\mathrm{m} \mathrm{ka}^{-1}\right)\end{array}$ \\
\hline L11V707 & $-9.9+/-2.1$ & $0.9+/-0.9$ & 2.3 \\
L11V701 & $-14.0+/-2.3$ & $0.5+/-0.5$ & 4.1 \\
L41V502 & $-15.9+/-1.4$ & $1.5+/-1.5$ & 0.9 \\
L41V503 & $-36.5+/-1.5$ & $1.3+/-1.3$ & 1.1 \\
L41V504 & $-44.2+/-0.6$ & $0.5+/-0.5$ & 1.1 \\
L36V302 & $-18.6+/-2.3$ & $0.5+/-0.5$ & 4.6 \\
L36V301 & $-32.7+/-1.9$ & $0.9+/-0.9$ & 1.9 \\
L33V305 & $-13.7+/-2.5$ & $0.7+/-0.7$ & 3.9 \\
L33V306 & $-32.7+/-2.3$ & $0.9+/-0.9$ & 2.6 \\
L24V102 & $-14.1+/-0.5$ & $1.5+/-1.5$ & 0.7 \\
L24V903 & $-49.1+/-0.7$ & $0.8+/-0.8$ & 0.8 \\
L23V103 & $-12.5+/-2.7$ & $0.9+/-0.9$ & 3.1 \\
L23V104 & $-16.8+/-0.5$ & $1.1+/-1.1$ & 0.4 \\
L23V105* & $-24.7+/-0.1$ & $1.9+-1.9$ & 0.1 \\
\hline N065: Seti & - &
\end{tabular}

Notes: Section elevation intervals $(\mathrm{m})$ and corresponding section ages (ka) of radiocarbon deposits and modern surfaces are used to calculate recent short-term sedimentation rates $\left(\mathrm{m} \mathrm{ka}^{-1}\right)$. Elevations and ages of the deposit $\mathrm{C}^{14}$ samples, ravinement surfaces and modern surfaces are from Table 4. 
Table 8: Post-ravinement sediment volumes for the CRLC inner-shelf transect segments.

\begin{tabular}{llll}
\hline Transect & $\begin{array}{l}\text { Along-shelf } \\
\text { segment }(\mathrm{m})\end{array}$ & $\begin{array}{l}\text { Cross-section } \\
\text { area }\left(\mathrm{m}^{2}\right)\end{array}$ & $\begin{array}{l}\text { Shelf segment } \\
\text { volume }\left(\mathrm{x} 10^{6} \mathrm{~m}^{3}\right)\end{array}$ \\
\hline L7 & 8080 & 2500 & 20 \\
L11 & 16570 & 40500 & 671 \\
L41 & 15330 & 77500 & 1188 \\
L46 & 14930 & 114800 & 1714 \\
L37 & 16430 & 176500 & 2900 \\
L36 & 10550 & 235500 & 2485 \\
L33 & 13900 & 402500 & 5595 \\
L24 & 11600 & 534600 & 6201 \\
L23 & 8960 & 273900 & 2454 \\
L19 & 10110 & 155900 & 1576 \\
\hline
\end{tabular}

Notes: Along-shelf segment lengths (m) for each across-shelf transect were calculated from mid-points between 1) transects, 2) the south bounding Tillamook Headland, and 3) the northern bound of shelf sand accumulation between transects L7 and L5 (Table 5). Transect cross-section areas are taken from Table 5. Shelf segment volumes $\left(\times 10^{6} \mathrm{~m}^{3}\right)$ are derived from the products of along-shelf segment length and corresponding transect cross-section areas. 


\section{Revision 5_01_16}

Highlights

This article combines onshore and offshore data on inner-shelf sedimentation in a highwave-energy inner-shelf setting of the NE Pacific Ocean. These data compilations test, possibly for the fist time, some fundamental relations between post-ravinement accommodation space and net sediment accumulation in a high-wave-energy inner-shelf that is abundantly supplied by fluvial sand discharged to the littoral zone. This article also points out the potential impacts of increasing inner-shelf accommodation space on longterm beach erosion following predicted increases in sea level rise from future global warming. 